\title{
Pharmaceutical design of a delivery system for the bacteriocin lacticin 3147
}

\author{
Aoibhín Ryan $^{1}$ (1) $\cdot$ Pratikkumar Patel $^{1} \cdot$ Paula M. O'Connor $^{2,3} \cdot$ R. Paul Ross ${ }^{3,4} \cdot$ Colin Hill $^{3,4} \cdot$ Sarah P. Hudson $^{1,5}$ (])
}

Accepted: 7 April 2021 / Published online: 19 April 2021

(c) The Author(s) 2021

\begin{abstract}
Lacticin 3147 is a dual-acting two-peptide bacteriocin which is generally active against Gram-positive bacteria, including Listeria monocytogenes and antimicrobial-resistant bacteria such as Closteroides difficile in the colon. L. monocytogenes infections can cause life-long effects in the elderly and vulnerable and can cause severe complications in pregnant women. C. difficile causes one of the most common healthcare-associated infections and can be fatal in vulnerable groups such as the elderly. Although lacticin 3147 is degraded by intestinal proteases and has poor aqueous solubility, encapsulation of the bacteriocin could enable its use as an antimicrobial for treating these bacterial infections locally in the gastrointestinal tract. Lacticin 3147 displayed activity in aqueous solutions at a range of $\mathrm{pH}$ values and in gastric and intestinal fluids. Exposure to trypsin and $\alpha$-chymotrypsin resulted in complete inactivation, implying that lacticin 3147 should be protected from these enzymes to achieve successful local delivery to the gastrointestinal tract. The amount of lacticin 3147 dissolved, i.e. its solution concentration, in water or buffered solutions at $\mathrm{pH} 1.6$ and 7.4 was low and varied with time but increased and was stabilized in gastrointestinal fluids by the phospholipid and bile salt components present. Thus, the feasibility of a solid lipid nanoparticle (SLN) delivery system for local administration of lacticin 3147 was investigated. Bacteriocin activity was observed after encapsulation and release from a lipid matrix. Moreover, activity was seen after exposure to degrading enzymes. Further optimization of SLN delivery systems could enable the successful pharmaceutical development of active lacticin 3147 as an alternative to traditional antibiotics.
\end{abstract}

Keywords Lacticin 3147 - Bacteriocins · Physicochemical properties · Solid lipid nanoparticles · Drug delivery · Antimicrobial resistance

\section{Introduction}

Antimicrobial resistance (AMR) occurs when microorganisms evolve in ways that render antibiotics ineffective. The number of bacteria becoming resistant to antimicrobial

Sarah P. Hudson

Sarah.Hudson@ul.ie

1 Department of Chemical Sciences, Bernal Institute, University of Limerick, Limerick, Ireland

2 Teagasc Food Research Centre Moorepark, Fermoy Co. Cork, Fermoy, Ireland

3 APC Microbiome Ireland Cork, Cork, Ireland

4 School of Microbiology, University College Cork, College Road, Cork, Ireland

5 SSPC the SFI Research Centre for Pharmaceuticals, University of Limerick, Limerick, Ireland drugs is rising constantly due to non-prudent use of antibiotics and the lack of new antimicrobials coming to the market [1-3]. Consequently, AMR is endangering the effectiveness of a range of drugs that have saved millions of lives [2]. It has been projected that by 2050 there could be 10 million deaths worldwide per annum due to AMR if this crisis is not tackled, exceeding the current number of deaths from cancer [4]. Because of this, alternatives to traditional antibiotics, such as bacteriocins, are being investigated.

Bacteriocins are small, cationic, heat stable, polypeptides that are ribosomally produced by bacteria. Bacteriocins inhibit the growth of competing bacterial strains by targeting the cell membrane and/or cell wall or by targeting vital processes within the cell, including protein, DNA, and RNA metabolism [5]. The Biopharmaceutical Classification System (BCS) is used to classify small molecule active pharmaceutical ingredients (APIs) based on their aqueous solubility and permeability [6]. The knowledge of a small 
molecule API's BCS class immediately leads to formulation strategies and biowaivers that can expedite their development into medicines [7]. For bacteriocins, this classification system is somewhat limited. Stability (chemical and enzymatic), solubility, unfolding, adsorption to surfaces, aggregation, and permeability are important physicochemical and biophysical factors that must be taken into consideration to enable the development of these peptides into antibiotics [8]. In general, a more in-depth classification system than the BCS is required to expedite the development of peptide biopharmaceuticals.

Lacticin 3147 is a two-peptide ( $\operatorname{Ltn} \alpha$ and $\operatorname{Ltn} \beta)$ bacteriocin produced by Lactococcus lactis DPC6577 (Fig. 1). It is classified as a lantibiotic due to the presence of lanthionine rings in its structure [9]. The two peptides act synergistically, targeting lipid II, a precursor of peptidoglycan synthesis in Gram-positive bacteria, leading to inhibition of cell wall synthesis, pore formation, and eventual cell death [10]. Ltn $\alpha$ exhibits low bacteriostatic activity when assayed alone, with a reported minimum inhibitory concentration required to inhibit the growth of $50 \%$ of bacteria $\left(\mathrm{MIC}_{50}\right)$ of $200 \mathrm{nM}$ against $L$. lactis HP. When equal concentrations of $L \operatorname{tn} \alpha$ and $\mathrm{Ltn} \beta$ are added, however, the $\mathrm{MIC}_{50}$ drops to $7 \mathrm{nM}$ indicating that the presence of both peptides at a 1:1 molar ratio allows for optimum activity [11]. $\operatorname{Ln} \beta$ alone has also shown bactericidal activity against $L$. lactis subspecies cremoris at high concentrations [12].
Lacticin 3147 is non-toxic to eukaryotic cells [13] and active at nanomolar concentrations against several clinically relevant bacteria, like L. monocytogenes, and antimicrobial-resistant bacteria such as $C$. difficile and methicillin-resistant $S$. aureus (MRSA) [14-16]. Approximately 223,900 C. difficile infections and 12,800 resulting deaths were reported in the USA in 2017 [17]. Treatment failures and recurrences of infection after the use of antibiotics are increasingly common, with a $2-38 \%$ failure rate for vancomycin and $8-50 \%$ for metronidazole [18]. A more virulent strain of $C$. difficile, PCR ribotype 027/NAP-1, which has recently been identified, is increasing the need for alternative therapies [19]. Around 323,700 clinical cases of MRSA were recorded in the USA in 2017 resulting in 10,600 deaths [17]. These figures highlight the urgent need for new treatment options for both $C$. difficile and MRSA infections. Although less threatening than $C$. difficile and MRSA, L. monocytogenes can be especially dangerous for pregnant women, leading to severe complications in pregnancy. It can result in lifelong health issues or death in the very young and can be fatal in elderly and immunocompromised people [20]. Oral administration of lacticin 3147 would allow for the treatment of $C$. difficile and L. monocytogenes infections, and its topical administration could be used to treat $S$. aureus, including MRSA, wound infections. However, the use of bacteriocins as medicines is limited due to their inherent physicochemical and biophysical properties.
Fig. 1 The structure of the lacticin 3147 peptides, Ltn $\alpha$ and Ltn $\beta$, illustrating the D-amino acid, D-alanine, the dehydrated amino acid, dehydrobutyrine (Dhb), and Ala-S-Ala, lanthionine, and Abu-S-Ala, $\beta$-methyllanthionine rings. The positively and negatively charged residues of the peptides are also indicated by plus and minus symbols

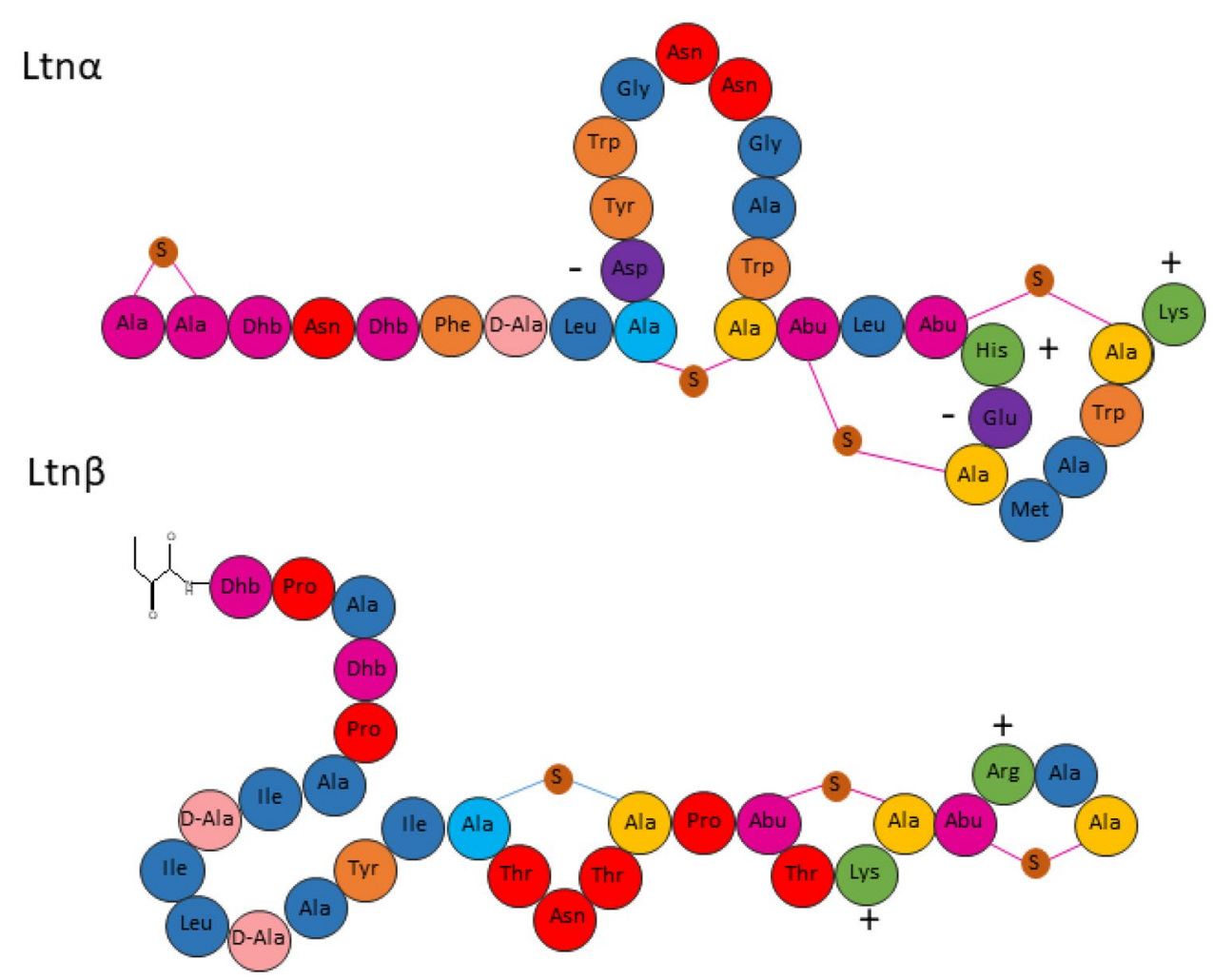


Ryan et al. reported that lacticin 3147 was degraded and inactivated by trypsin and $\alpha$-chymotrypsin, digestive enzymes found in the small intestines, but that its activity was unaffected by pepsin [9]. Gardiner et al., however, reported that $\alpha$-chymotrypsin alone degrades lacticin 3147 [21]. Lacticin 3147 is heat stable, $\mathrm{pH}$ stable, and active at a neutral $\mathrm{pH}$ [9]. However, quantitative data on the amount of lacticin 3147 dissolved, i.e. its solution concentration, is rarely reported. In fact, only a handful of quantitative solubility studies on bacteriocins can be found in the literature [22-24], with activity studies reported in their stead. Bacteriocins display low minimum inhibitory concentrations (MICs), and thus, only low solution concentrations of peptide are required to demonstrate activity. That said, in many cases, $\mathrm{pH}$ effects may reduce aqueous solution concentrations to below the MIC at different physiological locations, resulting in a loss in efficacy and could also result in the precipitation of peptide aggregates in vivo that could induce an undesirable immunogenic response.

Additionally, as many proteins are administered parenterally due to low bioavailability from oral administration [25], long-acting formulations are often desirable to reduce the need for frequent administration. Long-acting formulations can be achieved using inherently slow dissolving solid phases of the therapeutic or matrices that control the release of the therapeutic via diffusion or degradation of the matrix. For example, nisin A was released from solid lipid nanoparticles (SLNs) and pediocin AcH was released from phosphatidylcholine nanovesicles with sustained release of 15-20 days and 13 days respectively [26, 27]. To design such long-acting medicines, the solubility in both aqueous and non-aqueous solvent systems is an important parameter to ensure efficient encapsulation and the desirable resulting dissolution behaviour. This study investigates the stability, solution concentration, and activity of lacticin 3147 at a range of $\mathrm{pH}$ values and in solutions that mimic the gastrointestinal tract (Fasted State Simulated Gastric Fluid (FASSGF) and Intestinal Fluid (FaSSIF)). We explore the suitability of lipid formulations to protect lacticin 3147 against proteases. Lacticin 3147 encapsulated in solid lipid nanoparticles shows encouraging in vitro activity compared to free lacticin 3147 suggesting their potential as an alternative local oral treatment modality to eradicate pathogenic infections in the colon.

\section{Materials and methods}

\section{Materials}

L. Lactis DPC6577 was supplied by our collaborators in Teagasc Food Research Centre, Moorepark, Cork, Ireland. M17 broth, tryptic soy broth (TSB), tryptic soy agar (TSA),
XAD16N beads, $\beta$-glycerophosphate, ethanol, acetonitrile (ACN, $\geq 99.9 \%$ ), isopropanol (IPA, $\geq 99.9 \%$ ), methanol ( $\mathrm{MeOH}, \geq 99.9 \%$ ), acetone, phosphate-buffered saline (PBS), trifluoroacetic acid (TFA, $\geq 99.9 \%$ ), sodium hydroxide $(\mathrm{NaOH})$, potassium chloride $(\mathrm{KCl})$, sodium phosphate monobasic monohydrate, trypsin, $\alpha$-chymotrypsin, pepsin, sodium taurocholate hydrate $(\mathrm{NaTc},>97 \%), \mathrm{L}-\alpha-$ phosphatidylcholine (lecithin, $~ 99 \%$ purity, from bovine brain), Tween 80 , and hydrochloric acid ( $\mathrm{HCl}, 36.4-38 \%)$ were all purchased from Sigma-Aldrich Ireland Ltd. D-glucose, sodium chloride $(\mathrm{NaCl})$, yeast extract, tryptone, magnesium sulfate heptahydrate $(\mathrm{MgSO} 4.7 \mathrm{H} 2 \mathrm{O})$, and manganese(II) sulfate tetrahydrate $(\mathrm{MnSO} 4.4 \mathrm{H} 2 \mathrm{O})$ were purchased from Fisher Scientific Ireland Ltd. Sinapinic acid was purchased from Bruker. Biorelevant fasted state simulated intestinal fluid (FaSSIF) powder was purchased from Biorelevant.com Ltd. Geleol ${ }^{\mathrm{TM}}$ mono and diglycerides and Transcutol ${ }^{\circledR} \mathrm{P}$ were gift samples from Gattefossé, France. Kolliphor ${ }^{\circledR}$ RH40 was received as a gift from BASF, Germany. Deionized water was obtained from the Elga PURELAB system.

\section{The production and purification of lacticin 3147}

Lacticin 3147 was produced and purified following a protocol developed by Rea et al. [14]. Briefly, lacticin 3147 was purified from clarified TY broth using Amberlite XAD $16 \mathrm{~N}$ resin, C18 Solid Phase Extraction (SPE), and finally, lacticin 3147 was separated into its individual peptides, Ltn $\alpha$ and $\operatorname{Ltn} \beta$, by reversed-phase (RP) HPLC.

\section{MALDI-TOF mass spectrometry}

Lacticin 3147 production was confirmed by matrixassisted laser desorption ionization-time of flight (MALDI-TOF) mass spectrometry using sinapinic acid as the matrix [28]. About $0.7 \mu \mathrm{l}$ of the matrix solution (sinapinic acid, $4 \mathrm{mg} / \mathrm{ml}$ in $50 \%$ acetone $/ 50 \%$ methanol) was added to the target plate and left to evaporate (30 s) at ambient conditions. Individual peptides (Ltn $\alpha$ or $\operatorname{Ltn} \beta$ ) were resuspended in $70 \%$ IPA and mixed at a $1: 1$ volume ratio with a $10-\mathrm{mg} / \mathrm{ml}$ stock solution of sinapinic acid in $60 \%$ ACN with $0.1 \%$ TFA. About $0.3 \mu 1$ of this peptide-matrix solution was then added to the matrix layer previously applied to the plate and evaporated at ambient conditions. The plate was inserted into a MALDI-TOF Ultraflex mass spectrometer (Bruker) and analysed using reflectron positive 700-3500 Da mode. 100 shots were fired at $88 \%$ intensity. This method was also used for the analyses of samples from the enzyme degradation studies. 


\section{Bioactivity of lacticin 3147 versus $L$. monocytogenes ATCC 1916}

An overnight culture of L. monocytogenes ATCC1916 was grown in TSB media supplemented with $6 \mathrm{~g} / \mathrm{L}$ yeast at $37^{\circ} \mathrm{C}$. Freeze-dried $\operatorname{Ltn} \alpha$ and $\operatorname{Ltn} \beta$ were resuspended individually in 70\% IPA to make a $1-\mathrm{mg} / \mathrm{ml}$ solution and filtered through a $0.2-\mu \mathrm{m}$ filter (polyethersulfone) PES filter. They were then diluted in sterile PBS to a final peptide concentration of $50 \mu \mathrm{g} /$ $\mathrm{ml}$. Peptide solutions were added in triplicate to a 96-well plate with sufficient PBS to give a volume of $50 \mu \mathrm{l} .150 \mu \mathrm{l}$ of diluted bacterial cell culture (optical density (OD) of 0.1 at $595 \mathrm{~nm}$ ) was then added to the wells. Final peptide concentrations of $150 \mathrm{nM}(0.50 \mu \mathrm{g} / \mathrm{ml} \operatorname{Ltn} \alpha, 0.43 \mu \mathrm{g} / \mathrm{ml} \operatorname{Ltn} \beta), 300 \mathrm{nM}(0.99 \mu \mathrm{g} /$ $\mathrm{ml} \operatorname{Ltn} \alpha, 0.85 \mu \mathrm{g} / \mathrm{ml} \mathrm{Ltn} \beta)$, and $400 \mathrm{nM}(1.31 \mu \mathrm{g} / \mathrm{ml} \mathrm{Ltn} \alpha$, $1.14 \mu \mathrm{g} / \mathrm{ml} \operatorname{Ltn} \beta$ ) were obtained when the wells were filled to $200 \mu$ l. Blanks were set up in triplicate with media only and PBS only. The three control wells were also set up with bacterial culture and PBS only. The 96-well plate was incubated in a Biotek ELx808 Ultra microplate reader at $37{ }^{\circ} \mathrm{C}$ for $24 \mathrm{~h}$. Readings were taken at a wavelength of $590 \mathrm{~nm}$ every $30 \mathrm{~min}$ for $24 \mathrm{~h}$ with the plate shaken mildly before each reading.

\section{Preparation of buffers and fasted state simulated gastric and intestinal fluid without enzymes}

Phosphate-buffered saline $(1 \times, \mathrm{pH} 6.5)$ was prepared by dissolving one PBS tablet in $200 \mathrm{ml}$ of DI water on a magnetic stirrer. After complete dissolution of the tablet, the $\mathrm{pH}$ of the buffer was confirmed with a $\mathrm{pH}$ meter. Hydrochloric acid-potassium chloride $(\mathrm{HCl} / \mathrm{KCl})$ buffer was prepared by mixing $50 \mathrm{ml}$ of $200 \mathrm{mM} \mathrm{KCl}$ and $10.6 \mathrm{ml}$ of $200 \mathrm{mM} \mathrm{HCl}$ in a 100 -ml volumetric flask. The $\mathrm{pH}$ was then adjusted to $\mathrm{pH} 2.2$ with $1 \mathrm{M} \mathrm{NaOH}$, and the volume was made up to $100 \mathrm{~mL}$ with DI water. Fasted state simulated gastric fluid (FaSSGF) was prepared according to the method created by Vertzoni et al. [29], later amended by Bannigan et al. [30]. The final composition of the FaSSGF consisted of $80 \mu \mathrm{M} \mathrm{NaTc}, 20 \mu \mathrm{M}$ lecithin, $9.1 \mathrm{mM} \mathrm{NaCl}$, and $25.1 \mathrm{mM} \mathrm{HCl}$. FaSSIF was prepared according to the instructions provided by the manufacturer (Biorelevant, London, England). It had the final composition of $3 \mathrm{mM}$ taurocholate, $0.75 \mathrm{mM}$ phospholipid, $148 \mathrm{mM}$ sodium, $106 \mathrm{mM}$ chloride, and $29 \mathrm{mM}$ phosphate. The final solution was equilibrated for $2 \mathrm{~h}$ to stabilize the micellar particles as per manufacturer's recommendation. FaSSGF and FaSSIF were stored for $48 \mathrm{~h}$ at room temperature and used within this time frame.

\section{Lacticin 3147 's activity in phosphate-buffered saline, FaSSIF and FaSSGF}

An excess quantity of freeze-dried $\operatorname{Ltn} \alpha$ and $\operatorname{Ltn} \beta$ were resuspended individually in PBS buffer/FaSSGF/FaSSIF.
The samples were then incubated for $0.5 \mathrm{~h}$ at $37 \pm 0.5{ }^{\circ} \mathrm{C}$ with stirring at $300 \mathrm{rpm}$. At the end of the incubation period, samples were filtered through a 0.2- $\mu \mathrm{m}$ PES syringe filter and employed in the in vitro activity assay. Briefly, $25 \mu \mathrm{l}$ of each of the filtered peptide solutions were added in triplicate to the same wells of a 96-well plate. Three control wells were set up containing $50 \mu \mathrm{l}$ of PBS alone. $150 \mu \mathrm{l}$ of L. monocytogenes ATCC 1916 with an OD of 0.1 at $595 \mathrm{~nm}$ was added to each well. The 96-well plate was then incubated in a Biotek ELx 808 Ultra microplate reader at $37{ }^{\circ} \mathrm{C}$ for $24 \mathrm{~h}$. The readings were taken as previously described.

\section{RP-HPLC analysis of lacticin 3147}

All lacticin 3147 samples were filtered through a $0.2-\mu \mathrm{m}$ PES filter before analysis by RP-HPLC using an Agilent 1200 Infinity Series HPLC (Agilent Technologies, USA). The HPLC separations were carried out on an Aeris $3.6 \mu \mathrm{m}$ Peptide $100 \AA 250 \times 4.6 \mathrm{~mm}$, liquid chromatography column with a flow rate of $0.8 \mathrm{ml} / \mathrm{min}$, and with $0.1 \%$ trifluoroacetic acid (TFA) in water as aqueous phase-A and $0.1 \%$ TFA in acetonitrile (ACN) as organic phase- $\mathrm{B}$. The total run time was $51 \mathrm{~min}$. The mobile phase started with 30:70 A:B for $3 \mathrm{~min}$ and change linearly to $35: 65 \mathrm{~A}: \mathrm{B}$ over $30 \mathrm{~min}$. The organic phase was then adjusted to $100 \%$ within $1 \mathrm{~min}$ and continued to flow for $5 \mathrm{~min}$. After this, the mobile phase returned to the initial ratio to stabilize the chromatographic system. The detector was set at $214 \mathrm{~nm}$. The peak area (mAU) was plotted against the concentration $(1.56-500 \mu \mathrm{g} /$ $\mathrm{ml})$ to make a calibration curve. The coefficients of determination ( $R^{2}$ values) were 0.9963 and 0.9983 for $L \operatorname{tn} \alpha$ and $\operatorname{Ltn} \beta$ respectively. This method was subsequently used for quantitative analysis of $\operatorname{Ltn} \alpha$ and $\operatorname{Ltn} \beta$.

\section{Enzyme degradation of lacticin 3147}

Trypsin and $\alpha$-chymotrypsin stock solutions $(50 \mathrm{mg} / \mathrm{ml})$ were resuspended in water. Pepsin $(50 \mathrm{mg} / \mathrm{ml})$ was resuspended in $0.02 \mathrm{M} \mathrm{HCL}$. About $1 \mathrm{mg} / \mathrm{ml}$ individual solutions of $\operatorname{Ltn} \alpha$ and $\operatorname{Ltn} \beta$ in $70 \%$ IPA were filtered and diluted (1 in 20) in sterile PBS to give a final peptide concentration of $50 \mu \mathrm{g} / \mathrm{ml}$. After this, $5.3 \mu \mathrm{Ltn} \alpha$ and $4.6 \mu \mathrm{Ltn} \beta$ were added to the same well of a 96-well plate. An equal volume of enzyme was added to each well $(9.9 \mu \mathrm{l})$, giving the molar ratios as shown in Table 1 . The $\mathrm{pH}$ of the lacticin 3147-pepsin solution was 2.29. Control wells consisting of $L \operatorname{tn} \alpha$ and $\operatorname{Ltn} \beta$ together, $L \operatorname{tn} \alpha$ alone, and $\operatorname{Ltn} \beta$ alone with no enzyme were included. The 96 -well plate was incubated for $3 \mathrm{~h}$ at $37{ }^{\circ} \mathrm{C}$ to allow the enzyme to act. After incubation, the wells were filled to $50 \mu \mathrm{l}$ with PBS and $150 \mu \mathrm{l}$ of diluted bacterial cell culture (L. monocytogenes at an OD of 0.1 ) was added to each well. The final peptide concentration of $400 \mathrm{nM}(1.31 \mu \mathrm{g} / \mathrm{ml} \operatorname{Ltn} \alpha, 1.14 \mu \mathrm{g} / \mathrm{ml} \mathrm{Ltn} \beta)$ 
Table 1 The molar ratio of $\operatorname{Ltn} \alpha / \operatorname{Ltn} \beta$ to the digestive enzymes during the $3 \mathrm{~h}$ incubation period

\begin{tabular}{|c|c|c|}
\hline & $\begin{array}{l}\text { Molar ratio } \\
\text { Ltn } \alpha: \text { enzyme (nM) }\end{array}$ & $\begin{array}{l}\text { Molar ratio } \\
\text { Ltn } \beta \text { :enzyme } \\
(\mathrm{nM})\end{array}$ \\
\hline A-chymotrypsin & $1: 247$ & $1: 246$ \\
\hline Trypsin & $1: 265$ & $1: 264$ \\
\hline Pepsin & $1: 179$ & $1: 178$ \\
\hline
\end{tabular}

was obtained when the wells were filled to $200 \mu \mathrm{l}$. Blanks were set up in triplicate with media only and PBS only. The three control wells were also set up with bacterial culture and each enzyme only. The 96-well plate was incubated as previously described. The effect of the proteases pepsin, $\alpha$-chymotrypsin, and trypsin on the lacticin 3147 peptides was determined by MALDI-TOF mass spectrometry. A solution containing $25 \mathrm{mg} / \mathrm{ml}$ pepsin, $13.38 \mu \mathrm{g} / \mathrm{ml} \mathrm{Ltn} \alpha$, and $11.86 \mu \mathrm{g} / \mathrm{ml} \operatorname{Ltn} \beta$ was made up and left to incubate for $3 \mathrm{~h}(\mathrm{pH} 2.29, n=3)$. Blanks of $\operatorname{Ltn} \alpha$ and $\operatorname{Ltn} \beta$ alone and pepsin alone were included as control samples. After $3 \mathrm{~h}$, $1 \mu \mathrm{l}$ was removed from each sample and it was analysed by MALDI-TOF mass spectrometry. This was repeated for trypsin and $\alpha$-chymotrypsin (Scheme 1 ).

Pepsin's effect on lacticin 3147 was also investigated by RP-HPLC. A solution containing $60 \mathrm{mg} / \mathrm{ml}$ pepsin and $0.0625 \mathrm{mg} / \mathrm{ml} \mathrm{Ltn} \alpha$ and $\operatorname{Ltn} \beta$ was made up and was incubated at $37{ }^{\circ} \mathrm{C}$ for $3 \mathrm{~h}$. After incubation, aliquots were taken, filtered, and analysed by RP-HPLC to determine if pepsin degrades $\operatorname{Ltn} \alpha$ or $\operatorname{Ltn} \beta$ to any extent.

\section{The effect of $\mathrm{pH}$ and gastrointestinal simulated fluids on the solution concentration of lacticin 3147}

Solutions of the individual lacticin 3147 peptides $(500 \mu \mathrm{g} /$ $\mathrm{ml}$ ) were made up in $\mathrm{PBS}$ ( $\mathrm{pH} 7.4), \mathrm{HCl} / \mathrm{KCl}$ buffer $(\mathrm{pH}$ 2.2), FaSSGF (pH 1.6), FaSSGF without lecithin, FaSSGF without NaTc, and FaSSIF (pH 6.5). The solutions were stirred at $300 \mathrm{rpm}$ at $37^{\circ} \mathrm{C}$ for $0.5 \mathrm{~h}$, then placed in a shaking incubator at $60 \mathrm{rpm}$ and $37^{\circ} \mathrm{C}$. At $0.5 \mathrm{~h}, 5 \mathrm{~h}$, and $24 \mathrm{~h}$, $100 \mu \mathrm{l}$ aliquots of each sample were taken and analysed by RP-HPLC. Samples were only taken at $0.5 \mathrm{~h}$ and $24 \mathrm{~h}$ for lacticin 3147 in FaSSGF without lecithin and FaSSGF without NaTc.

\section{Micelle characterization}

Solutions of the individual lacticin 3147 peptides $(500 \mu \mathrm{g} /$ $\mathrm{ml}$ ) were prepared in FaSSIF, stirred at $300 \mathrm{rpm}$ at $37^{\circ} \mathrm{C}$ for $0.5 \mathrm{~h}$. At $0.5 \mathrm{~h}$, a $1-\mathrm{ml}$ aliquot was taken and filtered through a $0.2-\mu \mathrm{m}$ PES filter. It was analysed for micelle formation through dynamic light scattering (DLS) using the Malvern Nanozetasizer and a disposable plastic cuvette. The material selected was lipid (refractive index 1.5), and the dispersant

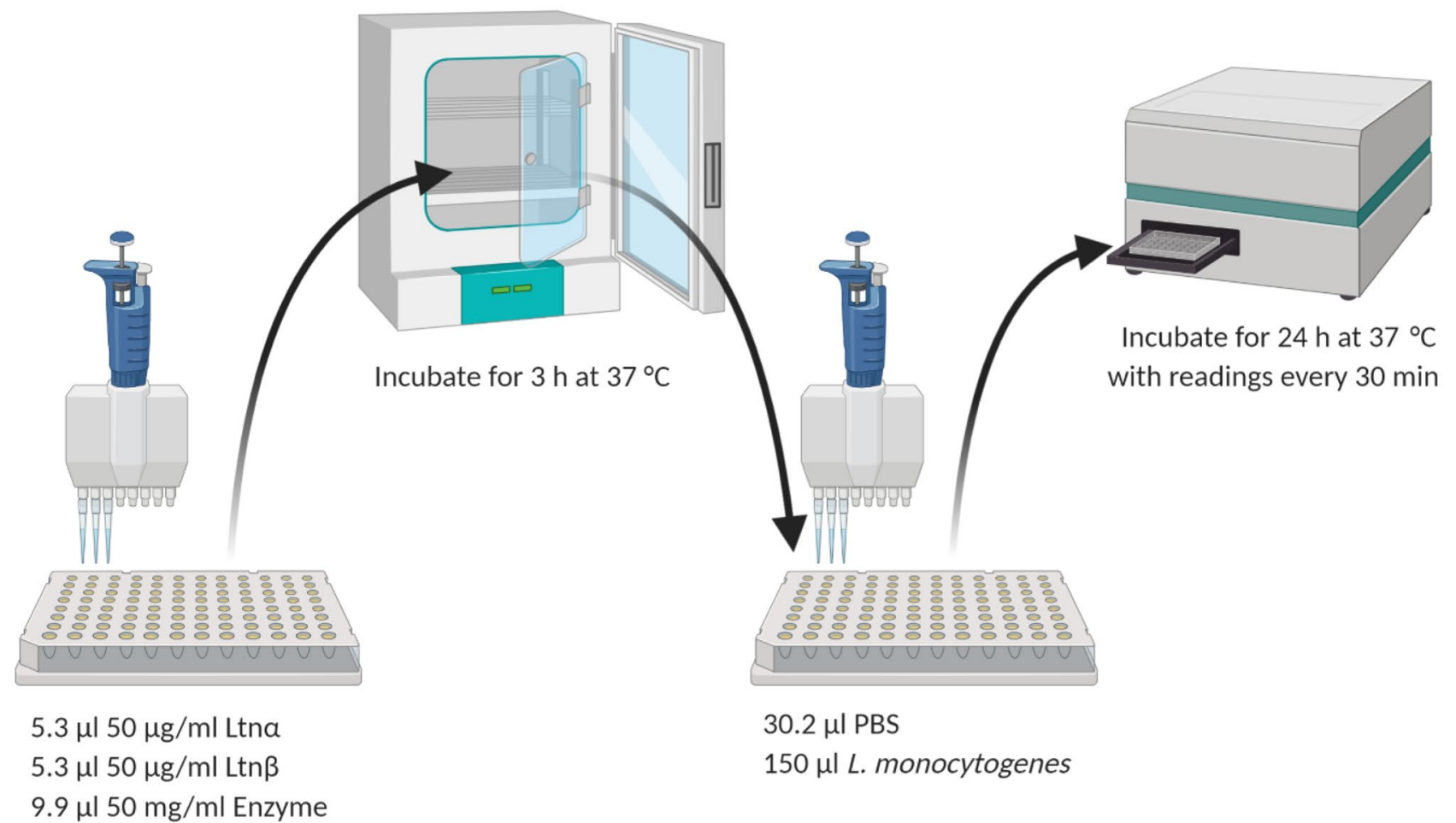

Scheme 1 Method used to determine the effect of trypsin, $\alpha$-chymotrypsin and pepsin on lacticin 3147 's activity 
was water (refractive index 1.33). The zeta potential was also determined using the same instrument and a disposable folded capillary cell.

\section{Encapsulation of lacticin 3147 into solid lipid nanoparticles}

\section{Preparation of the lacticin 3147 loaded SLNs}

SLNs were prepared using the microemulsion template technique reported in the literature [31]. About 3-6 mg of the individual lacticin 3147 peptides were solubilized in a mixture of lipid phase (0.055 $\mathrm{g}_{\text {Geleol }}{ }^{\mathrm{TM}}$ - $10 \%$ Lecithin) maintained at a temperature above its melting point $\left(65^{\circ} \mathrm{C}\right)$ with a surfactant-cosurfactant phase $\left(0.25 \mathrm{~g}\right.$ Kolliphore ${ }^{\circledR}$ RH 40:Transcutol® P, 2:1) and DI water $(0.7 \mathrm{ml})$. This formed a warm preconcentrate microemulsion which was sonicated for $3 \mathrm{~min}$ and then diluted in $5 \mathrm{ml}$ cold water $\left(2-8{ }^{\circ} \mathrm{C}\right)$ under stirring at 1000-1200 rpm for 5-7 min to form the SLNs dispersion (approximately $6 \mathrm{ml}$ ). The SLN solution was then filtered to remove any precipitated lacticin 3147. Similarly, blank SLNs were also prepared without adding lacticin 3147.

\section{Particle size distribution and zeta potential analysis of lacticin 3147 loaded SLNs}

The particle size and poly diversity index (PDI) of the SLNs were measured by photon correlation spectroscopy, using a Nanozetasizer (Malvern Instruments Ltd., Worcestershire, UK). Samples were diluted 50 times using DI water to guarantee that the dispersion was within the instrument's 'dynamic light scattering intensity' sensitivity range of light. The zeta potential of the concentrated solutions was also determined using the Nanozetasizer. Measurements were carried out in triplicate at $25{ }^{\circ} \mathrm{C}$. The refractive indexes selected were 1.5 for the dispersed phase (lipid) and 1.33 for the dispersant (water).

\section{Determination of total peptide content (TP), free peptide content (FP), and encapsulation efficiency (EE\%) of lacticin 3147 loaded SLNs}

To determine the total peptide content, lacticin 3147 loaded SLN dispersions were diluted with methanol, vortexed, and sonicated for $5 \mathrm{~min}$. The samples were filtered using a 0.2$\mu \mathrm{m}$ PES syringe filter and analysed by RP-HPLC as discussed in 'RP-HPLC analysis of lacticin 3147'. To establish the free peptide content of the SLN dispersions, they must be destabilized. This was done by adding $200 \mathrm{mg}$ of $\mathrm{NaCl}$ to $0.5 \mathrm{ml}$ of the dispersions followed by vortexing, then centrifugation for $10 \mathrm{~min}$ at $10,000 \mathrm{rpm}$. This separated the lipid $(\alpha$-SLN and $\beta$-SLN) and aqueous phases. The destabilized
SLN dispersion containing tube was carefully removed from the centrifuge and placed in the fridge for $10 \mathrm{~min}$ to allow the lipid layer to harden. Using a needle, the clear supernatant aqueous layer was removed, diluted with IPA, and centrifuged again. It was then filtered using a $0.2-\mu \mathrm{m}$ PES filter and analysed by RP-HPLC to detect the free peptide content. The concentration of encapsulated $\operatorname{Ltn} \alpha$ and $\operatorname{Ltn} \beta$ was determined by subtracting the free peptide content from total peptide content. The encapsulated efficiency of $\operatorname{Ltn} \alpha$ and $\operatorname{Ltn} \beta$ was calculated using the following calculation:

Encapsulation efficiency $(\%)=\frac{\text { total peptide }- \text { free peptide }}{\text { total peptide }} \times 100$

\section{Activity of lacticin 3147 SLNs vs free peptide}

The activity of the lacticin 3147 SLNs was evaluated using the well diffusion assay method [32], on TSA supplemented with $6 \mathrm{~g} / \mathrm{L}$ yeast. The inhibition zones were reported in millimetre $(\mathrm{mm})$ using electronic Vernier callipers. Briefly, TSA plates were inoculated with $200 \mu \mathrm{l} L$. monocytogenes ATCC1916 (OD of 0.1 at $595 \mathrm{~nm}$ ) under aseptic conditions. Wells were bored in the agar after it hardened using a sterile 6 -mm cork borer. $\alpha$-SLN and $\beta$-SLN were filtered using a $0.2-\mu \mathrm{m}$ PES filter (SLNs can pass through), and $12.5 \mu \mathrm{L}$ of each was added to the same well. The blank SLNs were used as negative controls $(25 \mu \mathrm{L})$. $\operatorname{Ltn} \alpha(12.5 \mu \mathrm{L})$ and $\operatorname{Ltn} \beta$ $(12.5 \mu \mathrm{L})$ solutions were used as positive controls. Free Ltn $\alpha$ and $\operatorname{Ltn} \beta$ solutions with the same concentration as the TP content of the lacticin 3147 SLNs were suspended in water, vortexed, stirred for $5 \mathrm{~min}$ at $1100 \mathrm{rpm}$, and filtered to remove any undissolved lacticin 3147 . The free peptides were filtered again using a $0.2-\mu \mathrm{m}$ PES filter before addition to the wells to ensure sterility. All tests were performed in triplicate.

\section{Activity of lacticin 3147 SLNs after incubation with a-chymotrypsin vs free peptide}

$\alpha$-SLN and $\beta$-SLN were filtered using a $0.2-\mu \mathrm{m}$ PES filter, and $25 \mu \mathrm{l}$ of each were added to the same well of a 96-well plate. About $50 \mu \mathrm{l}$ of a $50 \mathrm{mg} / \mathrm{ml}$ solution of $\alpha$-chymotrypsin was added to these wells. A blank was set up with $50-\mu \mathrm{l}$ water instead of $\alpha$-chymotrypsin. This was repeated for free peptide solutions prepared as outlined above. The 96-well plate was incubated for $3 \mathrm{~h}$ at $37{ }^{\circ} \mathrm{C}$. The 96 -well plate was then removed from the incubator, and $25 \mu \mathrm{l}$ of each solution was added in triplicate to $6-\mathrm{mm}$ wells on TSA ( $6 \mathrm{~g} / \mathrm{L}$ yeast) plates inoculated with $200 \mu \mathrm{L}$. monocytogenes ATCC1916. The plates were incubated at $37^{\circ} \mathrm{C}$ for $24 \mathrm{~h}$, after which the inhibition zones were measured using an electronic Vernier callipers. 


\section{Results and discussion}

\section{Bioactivity of lacticin 3147}

Successful production and purification of lacticin 3147 from L. lactis DPC6577 were confirmed by MALDITOF mass spectrometry with masses of $3305.341 \mathrm{Da}$ and 2847.443 Da recorded for $L \operatorname{tn} \alpha$ and $L \operatorname{tn} \beta$ respectively (Fig. 2). These masses correspond with those previously reported in the literature [28]. Lacticin 3147's activity against various strains including $L$. monocytogenes and $C$. difficile has been previously reported in the literature [11, 14-16, 33, 34]; however, for the purpose of this study, $L$. monocytogenes was used to establish the impact of solution composition, $\mathrm{pH}$, and process parameters on its activity. Our studies found that lacticin 3147 fully inhibited $L$. monocytogenes ATCC1916 at a concentration as low as $0.99 \mu \mathrm{g} / \mathrm{ml} \operatorname{Ltn} \alpha$ and $0.85 \mu \mathrm{g} / \mathrm{ml} \operatorname{Ltn} \beta(300 \mathrm{nM})$ (Fig. 3a) via growth curve assays. Lacticin 3147 was also active against L. monocytogenes ATCC 1916 when filtered (to remove any undissolved lacticin 3147) after addition in excess to PBS (pH 7.4), FaSSGF (pH 1.6), and FaSSIF (pH 6.5) (Fig. 3b). This implies more than 0.99 and $0.85 \mu \mathrm{g} / \mathrm{ml}$, of $\operatorname{Ltn} \alpha$ and $\operatorname{Ltn} \beta$ respectively dissolved in each of these solutions. Ryan et al. reported that lacticin 3147 is active against L. lactis subsp. cremoris $\mathrm{HP}$ at a neutral $\mathrm{pH}$ [9]. Quantitative solution concentration data is important as dissolved lacticin 3147 is required for activity and for systemic distribution (if desired) in vivo. Lacticin 3147 precipitates/aggregates could also provoke an unwanted immune response in patients. The components of the media used during in vitro activity assays may be necessary for solubilization of the peptide masking solubility challenges that will occur in vivo. The amount of lacticin 3147 dissolved in, for example, an aqueous-based buffer such as PBS, or simulated bodily fluids such as gastrointestinal media, and the stability of these solutions in terms of precipitation from solution, has not previously been reported.

\section{Enzymatic degradation of lacticin 3147}

A study on the effect of the proteases $\alpha$-chymotrypsin, trypsin, and pepsin on the activity of lacticin 3147 was carried out (Fig. 4).

After 3-h incubation with pepsin, lacticin 3147 remains active and no increase in bacterial growth compared to lacticin 3147 alone can be seen (Fig. 4). This confirmed that pepsin does not degrade either lacticin 3147 peptide as previously determined by Ryan et al. and Gardiner et al. [9, 21]. When $L \operatorname{tn} \alpha$ and $L \operatorname{tn} \beta$ were incubated with trypsin and $\alpha$-chymotrypsin, a growth curve similar to that of the bacterial control can be observed implying that both $\alpha$-chymotrypsin and trypsin degrade at least one of the lacticin 3147 peptides.

Subsequently, MALDI-TOF mass spectrometry on the peptides-enzyme solutions after $3 \mathrm{~h}$ of incubation was performed (Fig. 5). In the $\alpha$-chymotrypsin-lacticin 3147 and trypsin-lacticin 3147 samples, no masses corresponding to intact Ltn $\alpha$ or Ltn $\beta$ can be observed (Fig. 5b and c), confirming that the absence of activity for these solutions in Fig. 4 is due to the degradation of both lacticin 3147 peptides by $\alpha$-chymotrypsin and trypsin. Masses corresponding to Ltn $\alpha$ and $\operatorname{Ltn} \beta$ can be seen in the pepsin-lacticin 3147 spectrum, verifying that neither lacticin 3147 peptide was degraded by pepsin.

As MALDI-TOF analysis can only tell us if the peptide is present in the sample or not and does not give the concentration of $\operatorname{Ltn} \alpha$ and $\operatorname{Ltn} \beta$ in solution after exposure to pepsin, RP-HPLC analysis was carried out on the peptidepepsin solutions (Fig. 6). It is important to note that the ratio of peptide $(62.5 \mu \mathrm{g} / \mathrm{ml} \mathrm{Ltn} \alpha / \operatorname{Ltn} \beta)$ to pepsin $(60 \mathrm{mg} /$ $\mathrm{ml}$ pepsin) used here is not the same as that used for the activity test or the MALDI-TOF analysis. A higher concentration of $\operatorname{Ln} \alpha / \operatorname{Ln} \beta$ was required to allow for the detection of the lacticin 3147 peptides by RP-HPLC to quantify any degradation if it is occurring. This was not repeated for $\alpha$-chymotrypsin or trypsin as the lacticin 3147 peptides were shown to be fully degraded by these enzymes via MALDI-TOF mass spectrometry analysis (Fig. 5b and c).
Fig. 2 MALDI-TOF mass spectra of lacticin 3147

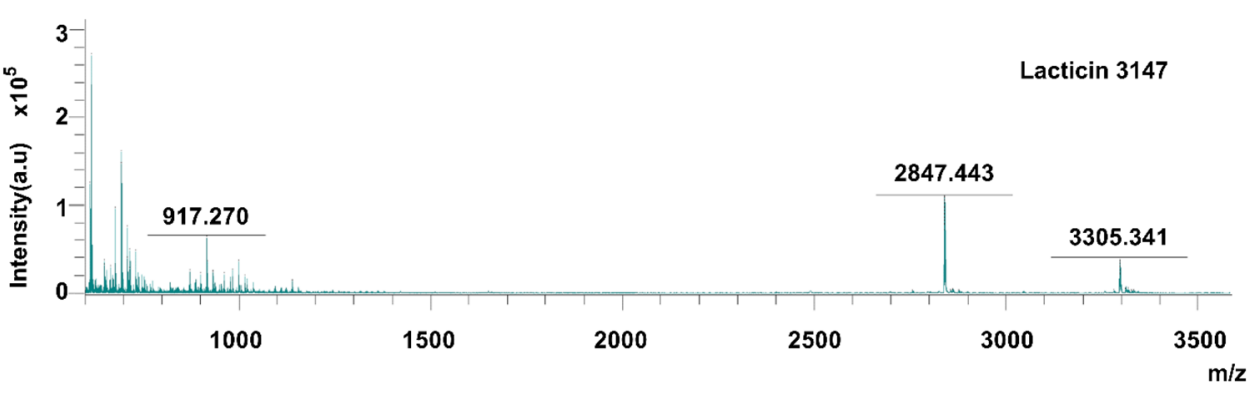


Fig. 3 The bioactivity of lacticin 3147 against $L$. monocytogenes ATCC 1916 when a) dissolved in $70 \%$ IPA, filtered, and then diluted in PBS and $\mathbf{b}$ ) resuspended in excess in PBS, FaSSGF, and FaSSIF and then filtered
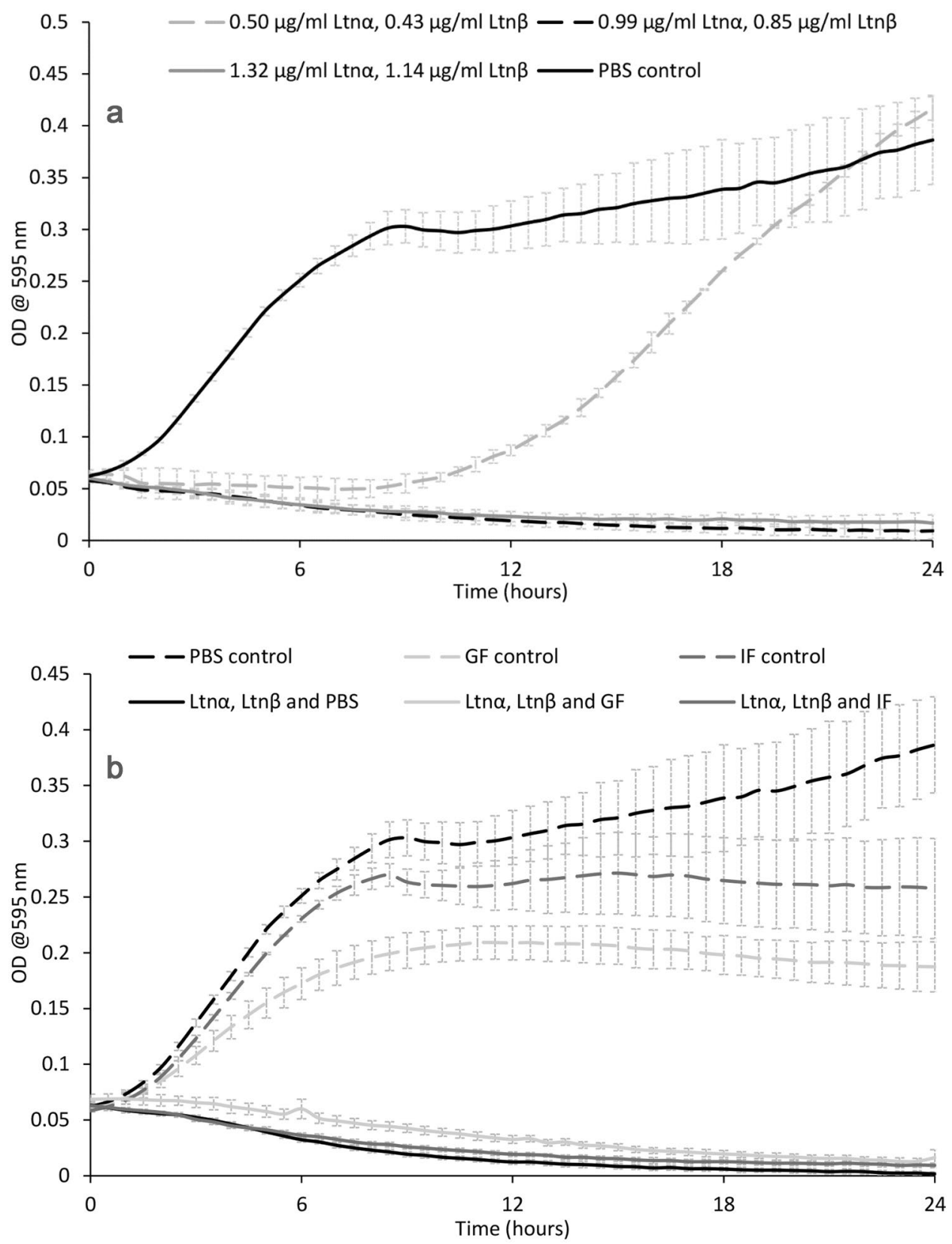

The concentrations of $\operatorname{Ltn} \alpha$ and $\operatorname{Ltn} \beta$ with and without pepsin are not significantly different (Fig. 6). This shows that neither peptide is degraded by pepsin to any detectable extent despite the presence of adjacent hydrophobic residues, which are targeted by pepsin, in Ltn $\alpha$ (Y11 and W12). The location of these target amino acids, in Ltn $\alpha$ 's lanthionine $\mathrm{B}$ ring, may shield them from the active site of pepsin. This is likely as rings A, C, and D were found to protect Ltn $\alpha$ from enzyme degradation by Suda et al. though ring $\mathrm{B}$ was not tested [35].

\section{The effect of pH and biorelevant media on the solution concentration of lacticin 3147}

Lacticin 3147 is active at very low concentrations. To quantify solution concentrations and monitor solution behaviour, a RP-HPLC method was developed. The lowest concentration detected, i.e. the limit of detection (LOD) of this method, was $1.56 \mu \mathrm{g} / \mathrm{ml}$. It is important to note that the concentration required for activity, $0.99 \mu \mathrm{g} / \mathrm{ml} \operatorname{Ltn} \alpha$ and $0.85 \mu \mathrm{g} / \mathrm{ml} \operatorname{Ltn} \beta$, is below the HPLC LOD. The consequence of this is that lacticin 
Fig. 4 The effect of $25 \mathrm{mg} / \mathrm{ml}$ pepsin, $\alpha$-chymotrypsin, and trypsin on lacticin 3147 's activity against $L$. monocytogenes ATCC 1916

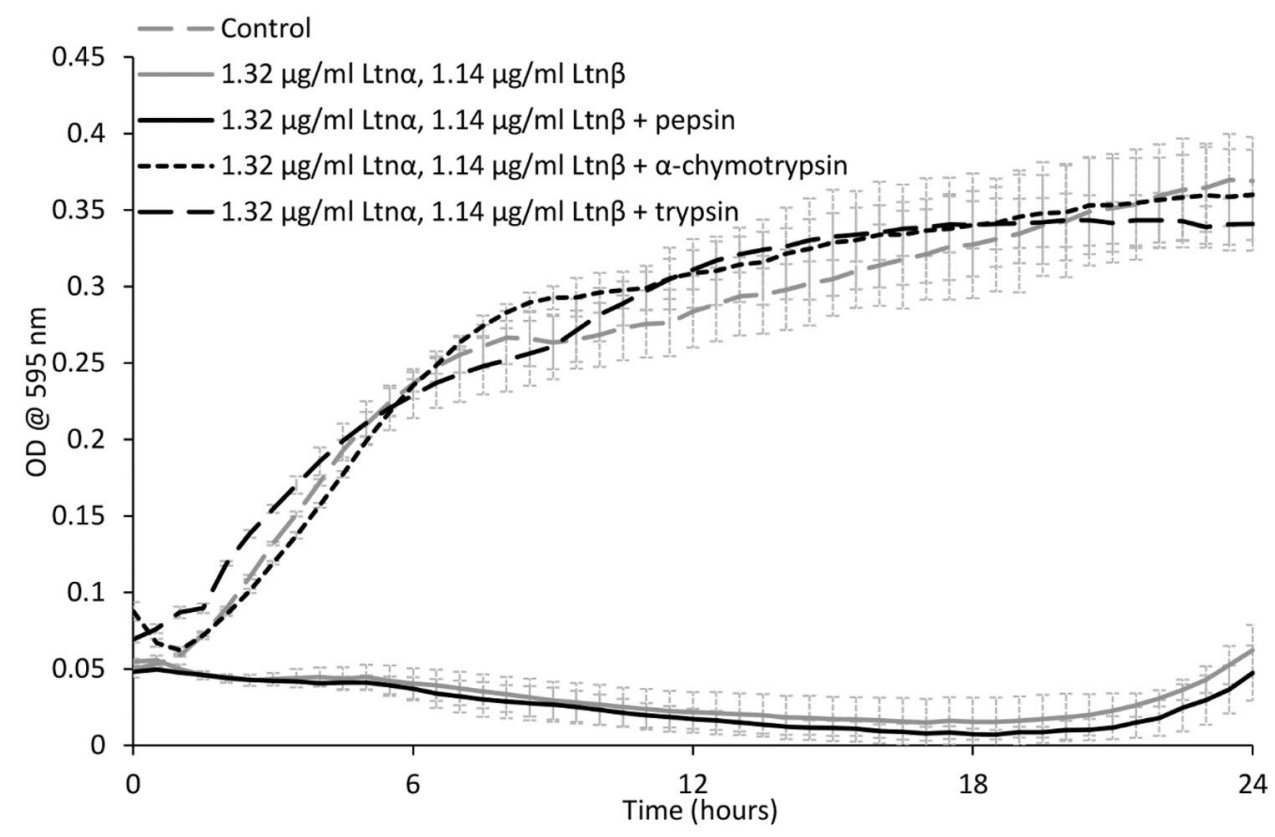

3147 may not be detectable in solution by HPLC, but there may still be enough dissolved to show activity.

Ltn $\alpha$ and Ltn $\beta$ 's solution concentration at different $\mathrm{pH}$ and in biorelevant media was measured. The results of this study can be seen in Fig. 7.

A low and variable concentration of dissolved Ltn $\alpha$ and $\mathrm{Ltn} \beta$ can just be detected in solution in PBS buffer and $\mathrm{HCl} /$ $\mathrm{KCl}$ buffer. No 24-h time point was taken for $\operatorname{Ltn} \beta$ in either of the buffer solutions due to the absence of a peak on the HPLC chromatogram at the 5-h time point, indicating that there was no detectable peptide in solution. It is not surprising that $\operatorname{Ltn} \beta$ has a lower aqueous solution concentration than $\operatorname{Ltn} \alpha$ as it is the more hydrophobic peptide, requiring a higher \% ACN to elute it from the RP-HPLC column during purification. Concentrations of $1.7 \pm 2.6 \mu \mathrm{g} / \mathrm{ml}(\operatorname{Ltn} \alpha)$ and $2.8 \pm 3.9 \mu \mathrm{g} / \mathrm{ml}(\operatorname{Ltn} \beta)$ were detected in solution in PBS at $0.5 \mathrm{~h}$, almost double and triple the reported MIC required for Ltn $\alpha$ and $\operatorname{Ltn} \beta$ respectively, although large standard deviations indicate the instability of the solution. This implies that for an intravenous aqueous injection of more than double the reported MIC of lacticin 3147, solubilizers would be needed to stabilize the solution and prevent precipitation of the peptide in vivo. It also implies that PBS may not be a suitable storage buffer for lacticin 3147.

Ltn $\alpha$ and $\operatorname{Ltn} \beta$ have isoelectric points (pIs) of 5.32 and 8.65 respectively [36]. Thus, it was expected that $\operatorname{Ltn} \alpha$ and Ltn $\beta$ 's solution concentration would increase in a $\mathrm{pH} 2.2$ $(\mathrm{KCl} / \mathrm{HCl})$ solution compared to a $\mathrm{pH} 7.4$ (PBS) solution as both peptides would be further away from their isoelectric point (with a larger positive surface charge) at $\mathrm{pH} 2.2$. The highest concentration of dissolved Ltn $\alpha$ detected at $\mathrm{pH} 2.2$ $(11.6 \pm 18.1 \mu \mathrm{g} / \mathrm{ml}$ at $24 \mathrm{~h})$ was not significantly different from the highest concentration of dissolved Ltn $\alpha$ observed in PBS $(12.1 \pm 11.5 \mu \mathrm{g} / \mathrm{ml}$ at $5 \mathrm{~h})$. The solution concentration of $\mathrm{Ltn} \beta$ in PBS and the $\mathrm{KCl} / \mathrm{HCl}$ buffers at $0.5 \mathrm{~h}$ are also not significantly different, $2.8 \pm 3.9 \mu \mathrm{g} / \mathrm{ml}$ and $2.8 \pm 2.0 \mu \mathrm{g} /$ $\mathrm{ml}$ respectively.

Ltn $\alpha$ initially dissolved in FaSSGF and FaSSIF $(71.8 \pm 117.3 \mu \mathrm{g} / \mathrm{ml}$ and $53.5 \pm 80.8 \mu \mathrm{g} / \mathrm{ml}$ respectively), but these solution concentrations were extremely unstable and showed large standard deviations. The concentration of Ltn $\beta$ in FaSSGF and FaSSIF at all time points is higher and more stable than that of $\operatorname{Ltn} \alpha$ and also significantly higher than its concentration in $\mathrm{PBS}$ or $\mathrm{KCl} / \mathrm{HCl}$ buffer. About $164.3 \pm 2.1 \mu \mathrm{g} / \mathrm{ml}$ of $\operatorname{Ltn} \beta$ was found to dissolve in FaSSGF (pH 1.6) initially. and it did not change significantly over $24 \mathrm{~h}$ (Fig. 7). From an approximately $500 \mu \mathrm{g} / \mathrm{ml}$ solution of $\operatorname{Ltn} \beta$ in FaSSIF, almost $185.6 \pm 29.6 \mu \mathrm{g} / \mathrm{ml}$ was found to be in solution initially and decreased to $58.2 \pm 4.0 \mu \mathrm{g} / \mathrm{ml}$ at $24 \mathrm{~h}$. These results indicate that the components of the simulated gastrointestinal fluids solubilize both lacticin 3147 peptides, with a larger solubilising and stabilising effect on Ltn $\beta$ than Ltn $\alpha$.

The concentration of NaTc in FaSSGF, $80 \mu \mathrm{M}$, is below the critical micelle concentration (CMC) value for a $4: 1$ NaTc:lecithin solution, $250 \mu \mathrm{M}$ [37]. Thus, encapsulation into micelles can be ruled out as the cause for increased lacticin 3147 solubility in FaSSGF. However, Ltn $\alpha$ and Ltn $\beta$ must be interacting with the lecithin and NaTc molecules present, resulting in an increase in their solution concentration, since a higher concentration of $\operatorname{Ltn} \alpha$ and $\operatorname{Ltn} \beta$ in solution was observed in FaSSGF compared to in the $\mathrm{HCl} / \mathrm{KCl}$ pH 2 buffer. The solution concentration of $\operatorname{Ltn} \alpha$ and $\operatorname{Ltn} \beta$ in FaSSGF without lecithin and without NaTc was investigated 
Fig. 5 MALDI-TOF mass spectra of lacticin 3147 incubated for $3 \mathrm{~h}$ with a) water, b) $\alpha$-chymotrypsin, c) trypsin, and d) pepsin and compared to an $\alpha$-chymotrypsin/trypsin/pepsin blank
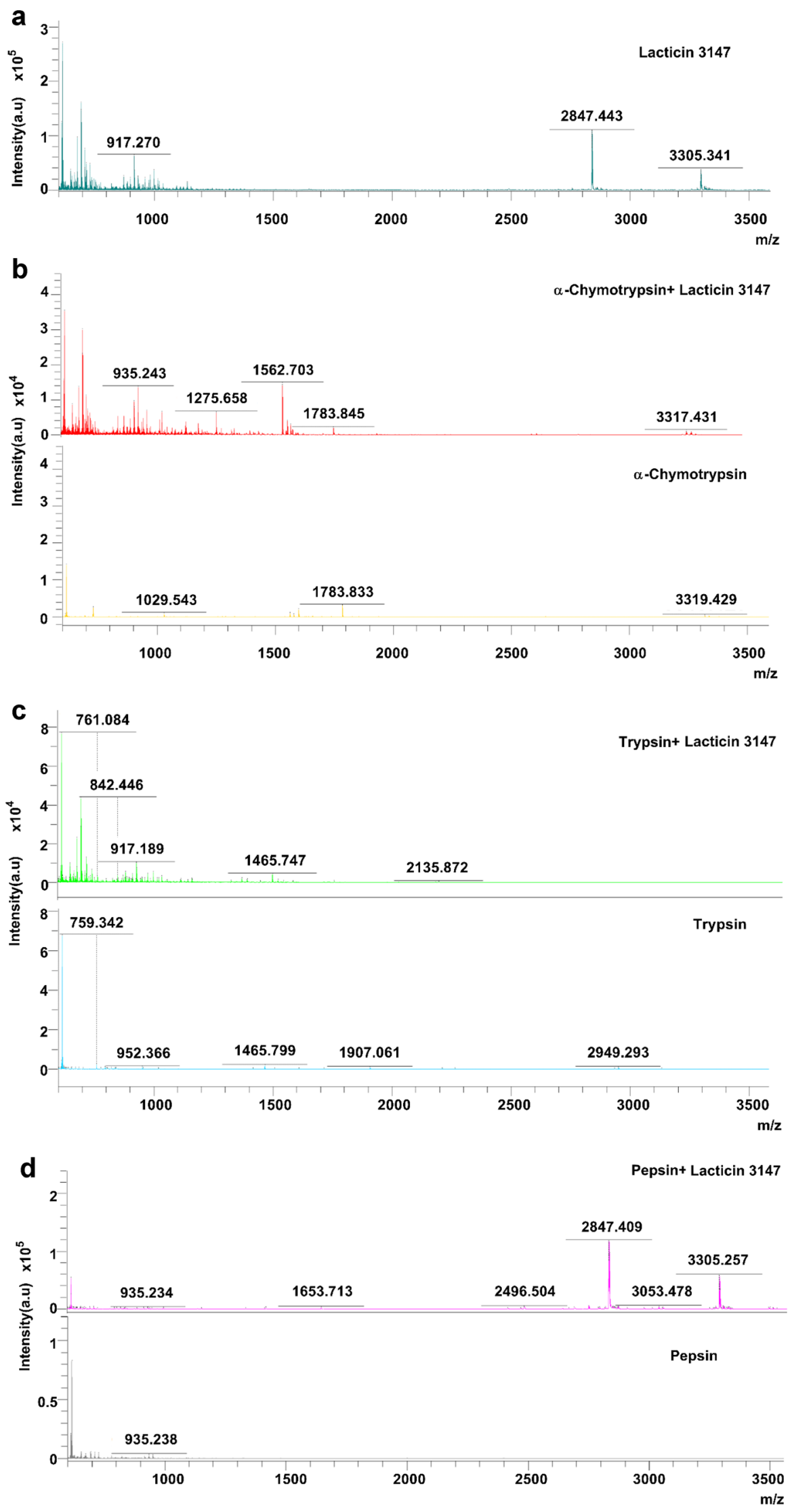
Fig. 6 Concentration of the individual lacticin 3147 peptides (approximately $62.5 \mu \mathrm{g}$ / $\mathrm{ml}$ ) with and without pepsin $(60 \mathrm{mg} / \mathrm{ml})$

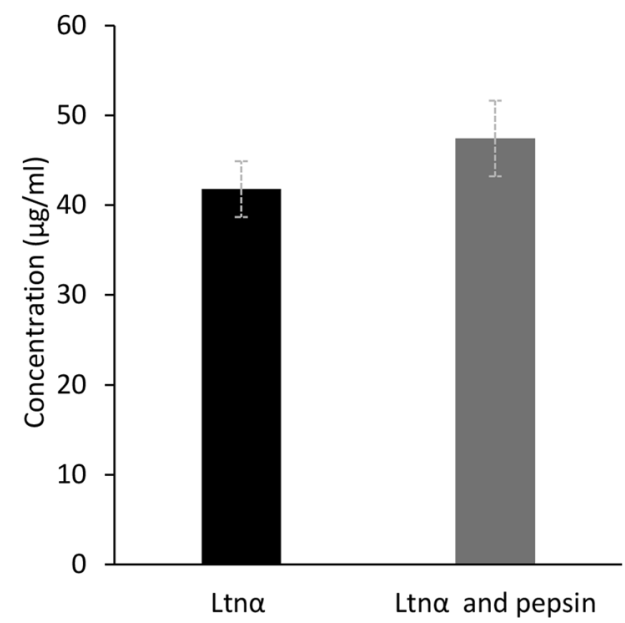

to determine the effect of the individual substances on the solution concentration of lacticin 3147 (Fig. 8).

From the above figure, it can be deduced that NaTc causes an increase in the solution concentration of $\operatorname{Ltn} \alpha$ and $\operatorname{Ltn} \beta$ but that lecithin is also required to keep $\operatorname{Ltn} \beta$ in solution.

The concentration of NaTc in FaSSIF, $3 \mathrm{mM}$, is above the CMC value for a 4:1 NaTc:phospholipid solution, $0.25 \mathrm{mM}$ [37]. Because of this, it is feasible that the increase in the concentration of dissolved Ltn $\alpha$ and $\operatorname{Ltn} \beta$ in FaSSIF could be due to their entrapment into micelles. $\operatorname{Ltn} \beta$ was more soluble and remains dissolved in the FaSSIF solution longer than Ltn $\alpha$ (Fig. 7). The entrapment of molecules into micelles relies on hydrophobic interactions between the hydrophobic tails of the lipids and the molecule. Therefore, the higher hydrophobicity of $\operatorname{Ltn} \beta$ could account for its higher concentration in solution. $\mathrm{Ltn} \beta$ is also positively charged at $\mathrm{pH}$ 6.5. This would also allow it to bind to the negatively charged head groups of the micelles or individual phospholipid and taurochlorate molecules, thus increasing the amount of $\operatorname{Ltn} \beta$ dissolved in solution. Ltn $\alpha$ is negatively charged at pH 6.5 and therefore, would be repelled from the head groups, and only encapsulation into the hydrophobic core of the micelles would increase its solution concentration.

To determine the presence of micelles in solution, FaSSIF was analysed by dynamic light scattering (DLS) with a zeta sizer in the nano range (Fig. 9). A peak was seen at $53 \mathrm{~nm}$ indicating that $\mathrm{NaTc} /$ phospholipid micelles are present in the FaSSIF solution. An increase in size of the micelles was observed in the FaSSIF solutions containing the lacticin 3147 peptides. This indicates the inclusion of both $\operatorname{Ltn} \alpha$ and Ltn $\beta$ into the micelle structure, although a larger increase in size with Ltn $\alpha$ was observed. This could perhaps be due to the repulsion of the negatively charged Ltn $\alpha$ from the charged head groups of the phospholipid and taurochlorate molecules and predominant encapsulation inside the hydrophobic core of the micelles. Zeta potential measurements were conducted to probe whether the $\operatorname{Ltn} \alpha$ or $\operatorname{Ltn} \beta$ interact with the ionic head groups of the micelles. The results showed an increase of zeta potential of +3.3 and $+5.5 \mathrm{mV}$
Fig. 7 Solution concentrations of Ltn $\alpha$ (left $n=3$ ) and $\operatorname{Ltn} \beta$ (right $n=2, \operatorname{FaSSIF} n=3$ ) after addition of $500 \mu \mathrm{g} / \mathrm{ml}$ peptide in PBS buffer, $\mathrm{HCl} / \mathrm{KCl}$ buffer, FaSSGF, and FaSSIF at $37^{\circ} \mathrm{C}$ with stirring at $300 \mathrm{rpm}$ for the first $0.5 \mathrm{~h}$ and subsequent shaking at $60 \mathrm{rpm}$ at $37{ }^{\circ} \mathrm{C}$ followed by filtration and HPLC analysis
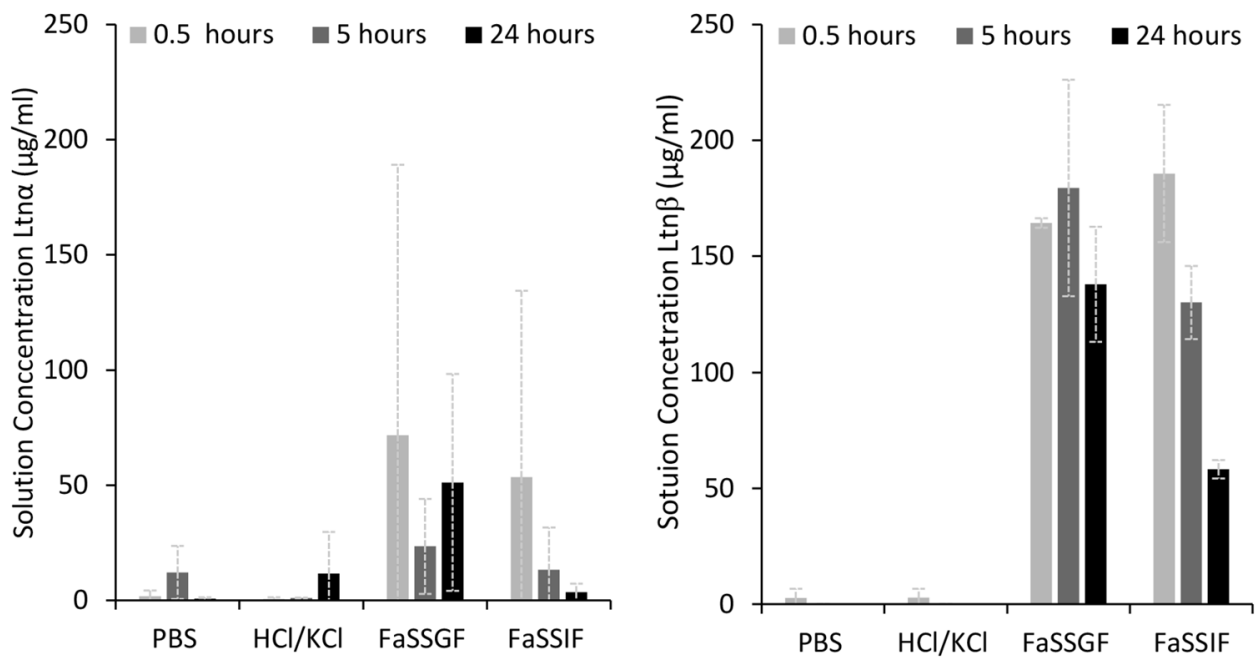
Fig. 8 Solution concentrations $(\mu \mathrm{g} / \mathrm{ml})$ of $\operatorname{Ltn} \alpha($ left $)$ and $\operatorname{Ltn} \beta$ (right) after addition of $500 \mu \mathrm{g} /$ ml peptide in FaSSGF (GF), GF without lecithin, and GF without NaTc at $37{ }^{\circ} \mathrm{C}$ with stirring at $300 \mathrm{rpm}$ for the first $0.5 \mathrm{~h}$ and subsequent shaking at $60 \mathrm{rpm}$
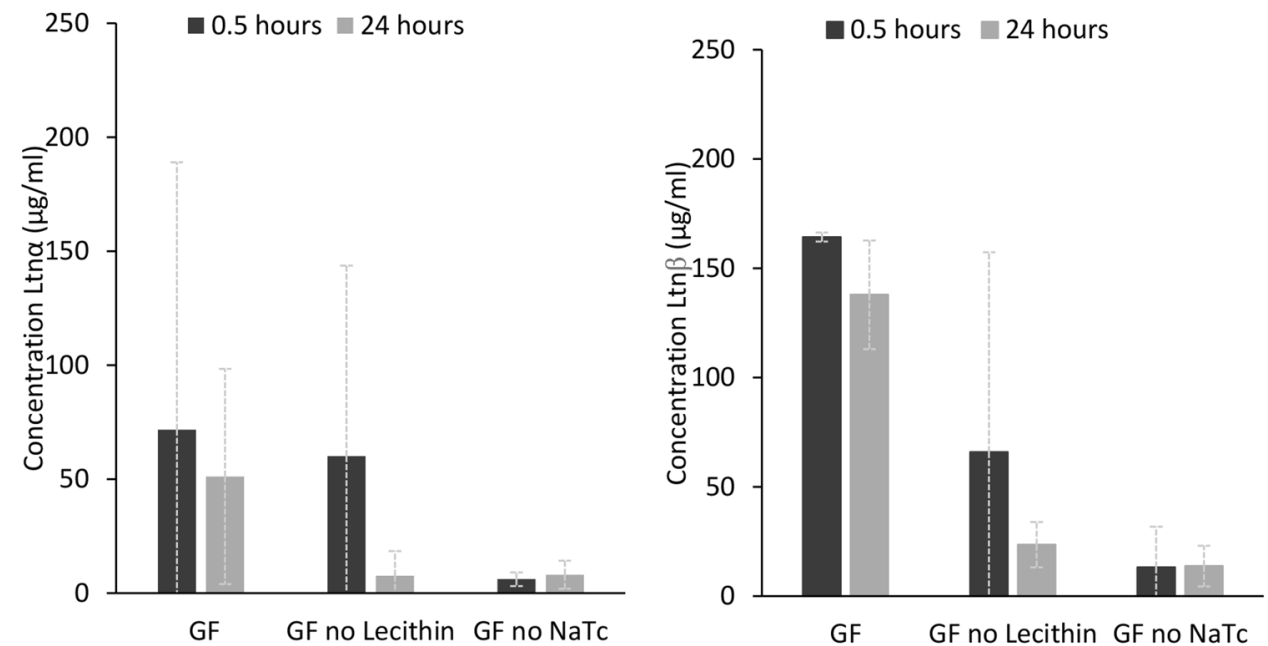

for FaSSIF containing $\operatorname{Ltn} \alpha$ and $\operatorname{Ltn} \beta$ respectively compared to FaSSIF alone after $24 \mathrm{~h}$. This indicated that while Ltn $\alpha$ appears to be encapsulated into the core of the micelles, increasing their size, the more favourable positive charge on $\operatorname{Ltn} \beta$ may increase binding to the micelle surface or individual phospholipid and taurochlorate molecules by electrostatic interactions, leading to a greater concentration of $\operatorname{Ltn} \beta$ in solution overall.

\section{Solid lipid nanoparticles as a formulation strategy for the delivery of lacticin 3147}

The low and unstable aqueous solubilities of $\operatorname{Ltn} \alpha$ and Ltn $\beta$ in PBS, Ltn $\alpha$ in FaSSGF and FaSSIF, and to a lesser degree, Ltn $\beta$ in FaSSGF and FaSSIF, mean that formulation strategies will be needed for all routes of administration of lacticin 3147. In PBS, solution concentrations only reached approximately double the required MIC against $L$. monocytogenes ATCC 1916 and these concentrations were unstable over time. This would be a cause for concern for parenteral administration [8]. At solution $\mathrm{pH}$ values below their $\mathrm{pI}$, the solubility of neither lacticin 3147 peptide improved. Thus, parenteral administration of lacticin 3147 solutions will require solubilising and stabilising additives to prevent aggregation and potential immunogenic responses in vivo. Lacticin 3147 displays hydrophobic characteristics in solution and an affinity to interact with the lipids and bile salts present in gastrointestinal (GI) fluid. This could be advantageous for its development into a topical lipid-based therapy, increasing its solubility and its permeability into the dermis and epidermis layers of the skin when treating $S$. aureus infections locally.
Fig. 9 Measurement of micelle size distribution in FaSSIF in the absence or presence of Ltn $\alpha$ or $\operatorname{Ltn} \beta$ at $0.5 \mathrm{~h}$

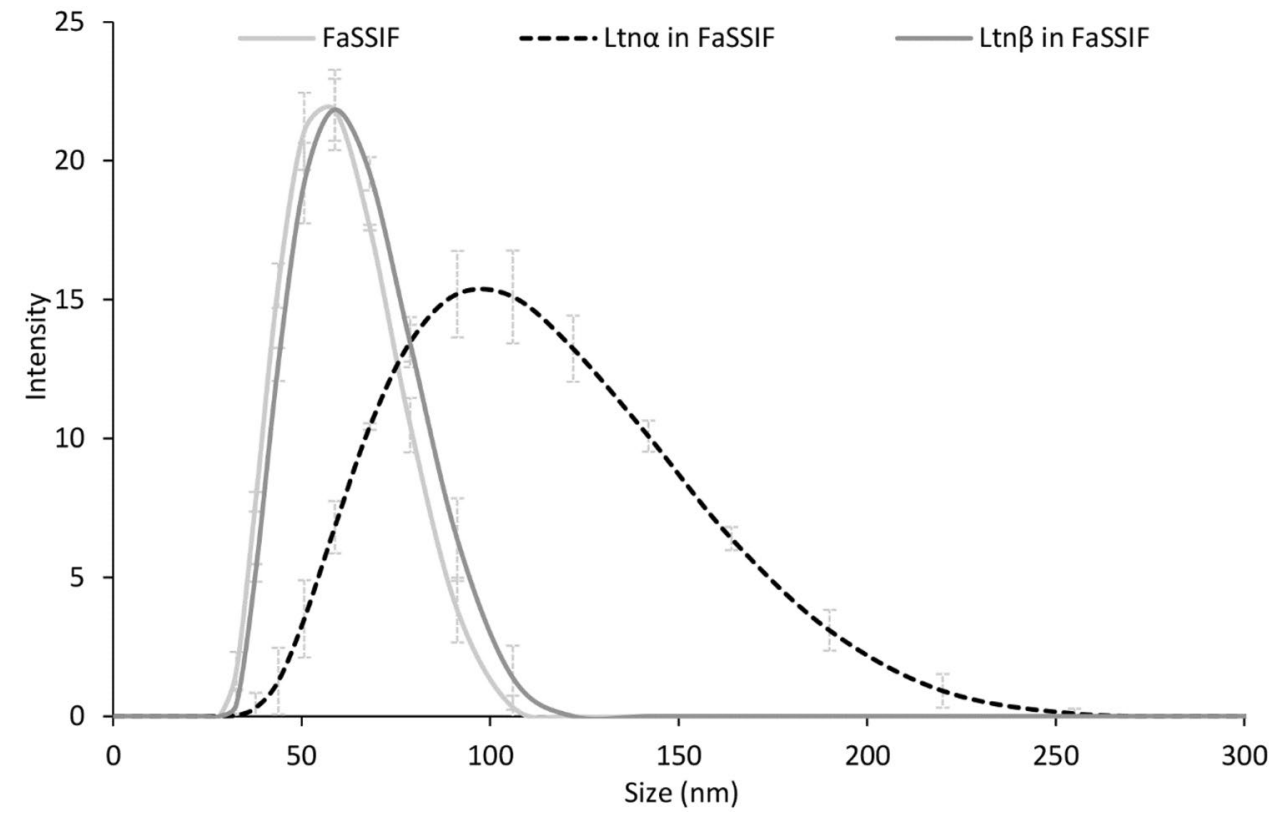


For oral administration, it was observed that the endogenous components of the GI tract enhanced the solubility of both $L \operatorname{tn} \alpha$ and $\operatorname{Ltn} \beta$. This is promising as L. monocytogenes and $C$. difficile infections in the colon are potential targets for lacticin 3147. Lacticin 3147, however, is susceptible to enzyme degradation by trypsin and $\alpha$-chymotrypsin in the lower digestive tract. Thus, to enable the lacticin 3147 peptides to act in the colon, they would need to be formulated in a way that protects them from this degradation. The degradation of lacticin 3147 by digestive enzymes could be overcome by nanocarrier based technology thus improving oral delivery efficiency. Amongst all nanocarriers, SLNs are considered to be superior for protection of actives against hostile GI environment by encapsulating actives in a solid matrix [38]. The increase in the solution concentration of lacticin 3147 caused by the presence of phospholipids and bile salts in FaSSGF/FaSSIF also indicates lipid systems as a potential suitable formulation strategy for lacticin 3147 . Additionally, SLNs can be produced on a large scale [26], are highly stable, and can improve the bioavailability of a drug [39]. They also show excellent biocompatibility, thus demonstrating wide acceptability by the human body [38, 40]. Thus, lacticin 3147 peptides were encapsulated in SLNs and their ability to protect $\operatorname{Ltn} \alpha$ and $\operatorname{Ltn} \beta$ from digestive enzymes was investigated.

Preliminary studies revealed better solubility of lacticin 3147 in geleol compared to other lipids (softisan 601 and glycerol monostearate) as determined by visual observation; hence, this was used for further studies. Geleol has the melting point between 54 and $64{ }^{\circ} \mathrm{C}$, therefore was melted at $65{ }^{\circ} \mathrm{C}$ and maintained at this temperature until the final dilution step. As lacticin 3147 is heat stable, its exposure to such a temperature should not affect its activity [9]. In the present work, an SLN preparation was carried out using a microemulsion templating technique whose composition was derived by plotting pseudoternary phase diagrams (data not shown). This technique does not require the use of any organic solvents or post-processing steps like probe sonication or homogenization [40]. Lecithin was incorporated into the lipid matrix as an additional stabilizer. To further reduce the interfacial tension and to impart stabilization on the SLNs, a cosurfactant was used together with the surfactants [41]. Several trials were conducted by varying the surfactant type (Kolliphore ${ }^{\circledR}$ H515, Kolliphore ${ }^{\circledR}$ RH40, Labrasol and polysorbate 80, and at a 2:1 ratio with the co-surfactant Transcutol $\left.{ }^{\circledR} \mathrm{P}\right)$ and the concentration of surfactant $(0.015-0.05 \mathrm{mg} / \mathrm{ml})$ and lipid $(0.005-0.01 \mathrm{mg} /$ $\mathrm{ml})$. Amongst all, Kolliphore ${ }^{\circledR} \mathrm{RH}: 40-$ Transcutol P (2:1) at $0.042 \mathrm{mg} / \mathrm{ml}$ and Geleol-10\% lecithin at $0.0092 \mathrm{mg} / \mathrm{ml}$ gave stable solid lipid nanoparticles (Scheme 2).

The particle sizes obtained for $\operatorname{Ltn} \alpha, \operatorname{Ltn} \beta$, and blank SLNs, irrespective of the exact mass of peptide added, were $85 \pm 3 \mathrm{~nm}$ (PDI: $0.22 \pm 0.01), 81 \pm 8 \mathrm{~nm}$ (PDI: $0.21 \pm 0.01$ ), and $82 \pm 15 \mathrm{~nm}$ (PDI: 0.22 ) respectively. This demonstrates that there was no significant difference in the size of the SLNs in any of the batches with or without peptides. Similarly, the encapsulation of the bacteriocin nisin $\mathrm{Z}$ into nano micelles by Sadiq et al. did not cause a significant increase in size [42]. The particle sizes obtained here are similar to that reported in the literature for local delivery to the colon [43, 44]. The narrow PDIs of these dispersions indicate homogeneous SLNs of uniform size. The encapsulation of $\operatorname{Ltn} \alpha$ and $\operatorname{Ltn} \beta$ increased the zeta potential of the SLNs by $+4.6 \pm 0.9$ and $+3.6 \pm 0.3$ respectively. This value was irrespective of the mass of each peptide added in the range of peptide loadings used, 3-6 mg. The increase of the zeta potential indicates that there must be some interaction between the peptides and the SLN surface composition.

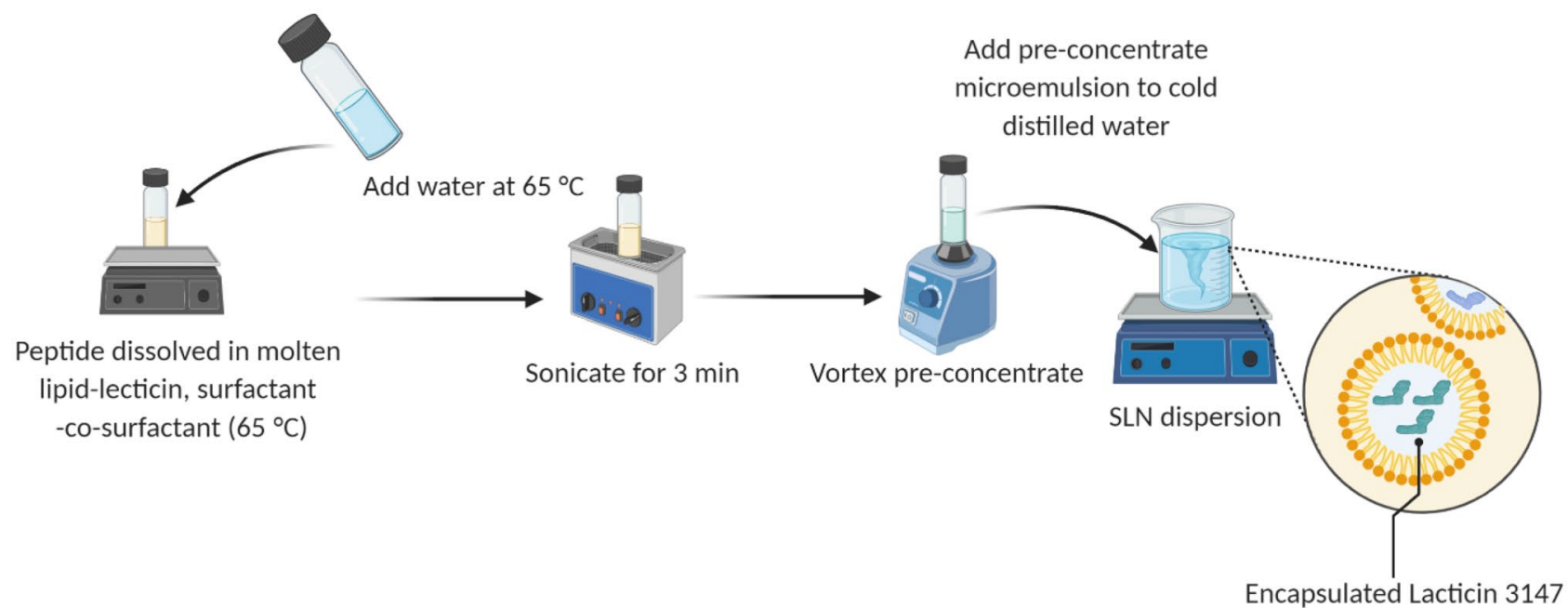

Scheme 2 Method used to prepare solid lipid nanoparticles of lacticin 3147 
The encapsulation efficiency of $\operatorname{Ltn} \alpha$ was $16 \pm 6 \%$, while the encapsulation efficiency of $\operatorname{Ltn} \beta$ was $84 \pm 8 \%$. $\operatorname{Ltn} \beta$ has previously shown to be the more hydrophobic peptide where the presence of micelles in FaSSIF led to a greater increase in solubility for $\operatorname{Ltn} \beta$ than $\operatorname{Ltn} \alpha$. Thus, it is not surprising that a higher encapsulation efficiency was obtained for $\operatorname{Ltn} \beta$ into the hydrophobic geleol SLNs.

An in vitro well diffusion assay (WDA) was performed to evaluate the activity of encapsulated peptide in SLNs versus free peptides (Fig. 10). A WDA was chosen instead of growth curve assays previously used for the previous activity studies as complete killing was seen for both solutions when tested by growth curve assays. The WDA method allowed for the extent of killing by each to be compared. The free peptides were suspended in water at the same concentration as the total peptide content determined for the lacticin 3147 SLNs used in the assay. The free peptide suspensions were vortexed briefly, stirred for $5 \mathrm{~min}$ at $1100 \mathrm{rpm}$, and then filtered to remove any undissolved lacticin 3147 . They were filtered again before addition to the agar plate to ensure sterility.
The larger zone of inhibition observed with the lacticin 3147 SLNs, $17.6 \pm 0.5 \mathrm{~mm}$, compared to those observed with free lacticin $3147,12.9 \pm 0.3 \mathrm{~mm}$, indicates (i) the retention of activity of $\operatorname{Ltn} \alpha$ and $\operatorname{Ltn} \beta$ post encapsulation and (ii) an increase in antimicrobial activity in water due to the encapsulation into SLNs. The amount of free peptide added to water in Fig. 10 (left) was the same as the total peptide content of the SLNs in Fig. 10 (right). Both the free lacticin 3147 peptide solutions and the $\alpha$-SLN and $\beta$-SLN suspensions were filtered before addition to the plate to remove any undissolved lacticin 3147 and ensuring sterility. Thus, the encapsulated peptides account for the larger inhibition zone observed, i.e. greater activity is seen in the $\alpha$-SLN and $\beta$-SLN plate compared to the aqueous solution of free $\operatorname{Ltn} \alpha$ and $\operatorname{Ltn} \beta$. No zone of inhibition was seen for the blank SLNs (Fig. 10 (bottom)), indicating that all killing observed in the lacticin 3147 samples were due to lacticin 3147 only and not the components of the SLNs.

As previously determined, $\operatorname{Ltn} \alpha$ and $\operatorname{Ltn} \beta$ are fully degraded by $\alpha$-chymotrypsin, leading to the loss of their activity. To determine if the encapsulation of the lacticin 3147 peptides into SLNs can protect them from enzymatic
Fig. 10 The zones of inhibition after the addition of combined free $L \operatorname{tn} \alpha$ and $\operatorname{Ltn} \beta$ solutions (left), combined $\alpha$-SLN and $\beta$-SLN dispersions (right), and blank SLN dispersions (bottom) against $L$. monocytogenes ATCC 1916. All samples were filtered before addition to the wells $(n=2)$

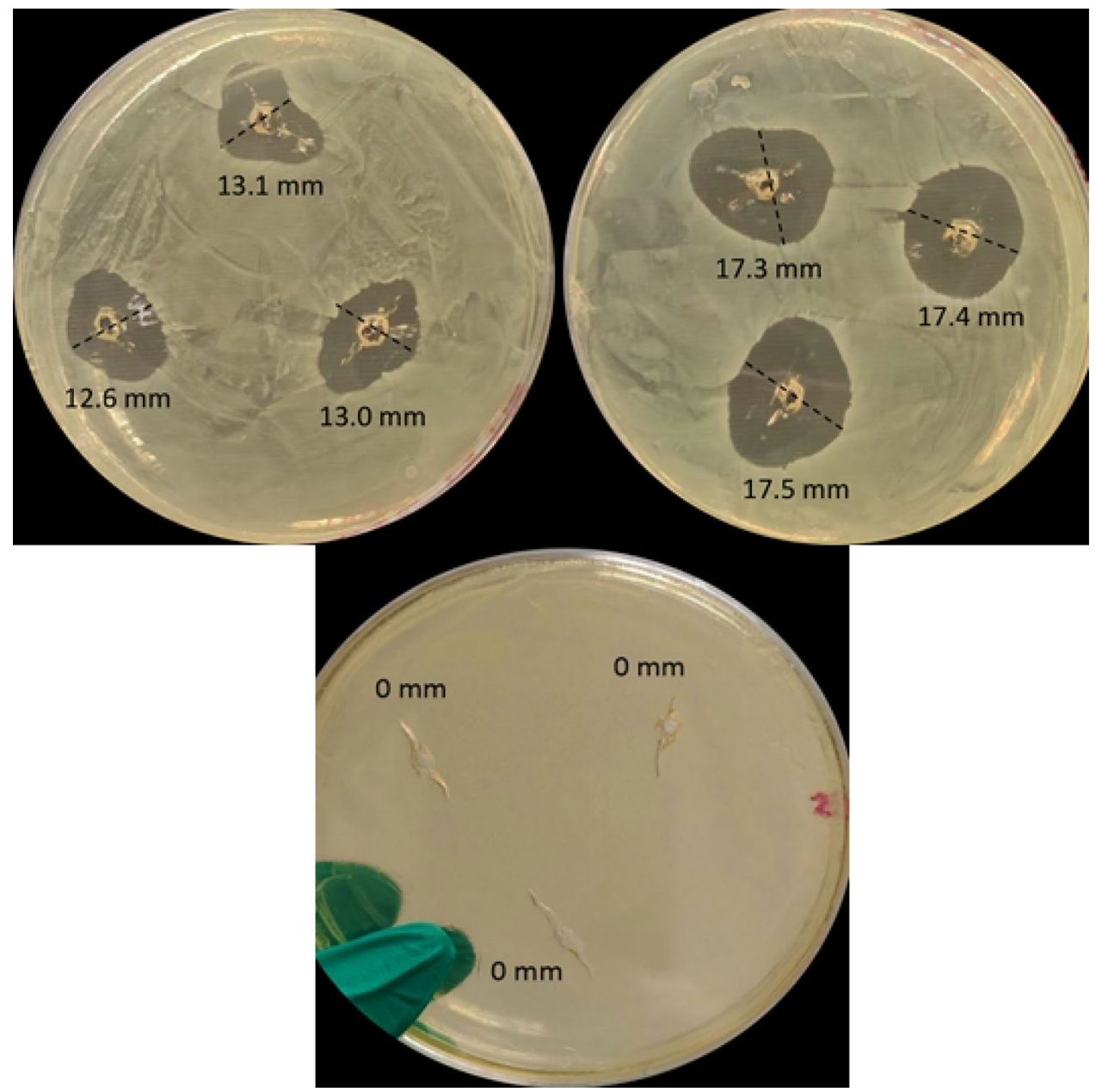


Fig. 11 The zones of inhibition after the addition of free lacticin 3147 (left) and lacticin 3147 SLNs (right) after incubation at $1: 1$ with $50 \mathrm{mg} / \mathrm{ml}$ $\alpha$-chymotrypsin for $3 \mathrm{~h}(n=2)$ against $L$. monocytogenes ATCC 1916

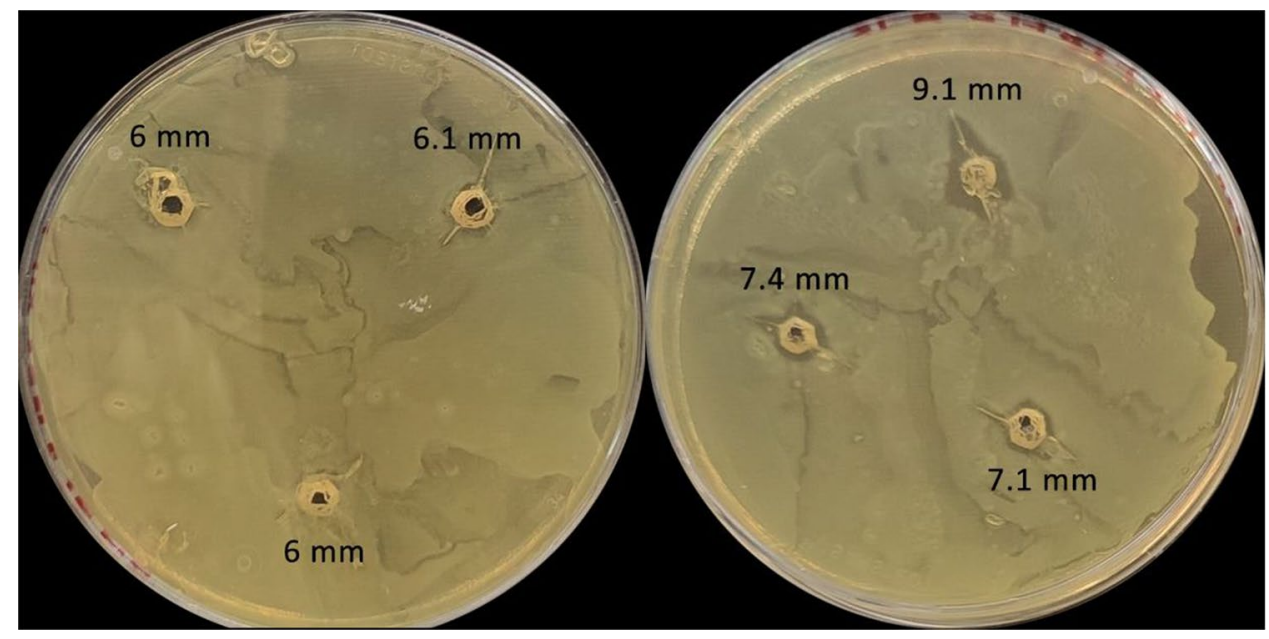

degradation, both free $\operatorname{Ltn} \alpha$ and $\operatorname{Ltn} \beta$ and $\alpha$-SLN and $\beta$-SLN were incubated with $\alpha$-chymotrypsin and then tested for activity (Fig. 11).

Small, yet significant, distinct zones of inhibition were present around the lacticin 3147 SLNs after incubation with $\alpha$-chymotrypsin (Fig. 11 (left)), of size $7.4 \pm 0.9 \mathrm{~mm}$, compared to barely visible zones with the free peptides incubated with the same, $6.0 \pm 0.1 \mathrm{~mm}$ (Fig. 11 (right)). This indicates the ability of the SLNs to protect lacticin 3147 from degradation by this enzyme to some extent. It is important to note, however, that $\alpha$-chymotrypsin is still active during the 24-h incubation with $L$. monocytogenes. This means that although lacticin 3147 was protected by the SLNs during the 3 -h incubation with $\alpha$-chymotrypsin, some of the peptides are likely to have been degraded when released out of the SLNs while in the wells of the agar plate. The zones of inhibition present are caused by the lacticin 3147 that survived degradation throughout the 24-h incubation (as the enzyme was not deactivated during this incubation period), meaning that the protective effect of the SLNs seen here may be less than what would be seen after only $3 \mathrm{~h}$ of incubation with $\alpha$-chymotrypsin. Further studies are required to determine the exact level of protection they provide.

Successful encapsulation and retention of activity of $\operatorname{Ltn} \alpha$ and $\operatorname{Ln} \beta$ indicate the feasibility of SLNs as a delivery system of lacticin 3147. The ability of the SLNs to protect the lacticin 3147 peptides from degradation by $\alpha$-chymotrypsin indicates their potential for delivering intact lacticin 3147 to treat infections in the intestine or colon.

\section{Conclusion}

Lacticin 3147 was shown to have low and unstable aqueous solution concentrations over a range of $\mathrm{pH}$ solutions from $\mathrm{pH} 1.6$ to $\mathrm{pH} 7.4$, despite demonstrating activity at such $\mathrm{pH}$ values. This activity is due to lacticin 3147 's potency and low MIC values. A bioactive's physicochemical properties can suggest potential delivery strategies early on that may enable its success at later stages of development. Lacticin 3147 's poor aqueous solubility and susceptibility to proteolytic degradation will necessitate solubilization and encapsulation strategies for its success in vivo. The increase in the solution concentration of lacticin 3147 peptides caused by the presence of phospholipid molecules and NaTc surfactant molecules in biorelevant media FASSIF indicated that lipid systems could be a potential formulation strategy. $L \operatorname{tn} \alpha$ and $L \operatorname{tn} \beta$ retained activity when encapsulated into solid lipid nanoparticles and demonstrated enhanced activity compared to free lacticin 3147 . Lacticin 3147 SLNs also showed activity after incubation with $\alpha$-chymotrypsin, displaying the potential ability of SLNs' to protect the lacticin 3147 peptides from degradation by this enzyme. Further optimization of such lipid delivery systems could deliver intact lacticin 3147 successfully to the colon to fight bacterial infections or indeed could increase the permeability of a lacticin 3147 topical treatment for infected wounds, enabling its development as an alternative to existing antibiotics.

Acknowledgements The authors would also like to thank Gattefosse, France, for Transcutol ${ }^{\circledR} \mathrm{P}$ and Geleol ${ }^{\mathrm{TM}}$ and BASF Germany for Kolliphor ${ }^{\circledR}$ RH 40. Graphical abstract was created with BioRender.com

Author contribution All co-authors contributed to the design and execution of the research and to the writing of the manuscript. Approval of the final version of the manuscript has been given by each of the co-authors.

Funding Open Access funding provided by the IReL Consortium This work was supported by the Irish Research Council (Grant GOIPG/2018/3041) and the Department of Chemical Sciences, University of Limerick, Ireland.

Availability of data and material All data and material is available on request from the corresponding author. 


\section{Declarations}

Conflict of Interest The authors declare no competing interests.

Open Access This article is licensed under a Creative Commons Attribution 4.0 International License, which permits use, sharing, adaptation, distribution and reproduction in any medium or format, as long as you give appropriate credit to the original author(s) and the source, provide a link to the Creative Commons licence, and indicate if changes were made. The images or other third party material in this article are included in the article's Creative Commons licence, unless indicated otherwise in a credit line to the material. If material is not included in the article's Creative Commons licence and your intended use is not permitted by statutory regulation or exceeds the permitted use, you will need to obtain permission directly from the copyright holder. To view a copy of this licence, visit http://creativecommons.org/licenses/by/4.0/.

\section{References}

1. Holmes AH, Moore LS, Sundsfjord A, Steinbakk M, Regmi S, Karkey A, et al. Understanding the mechanisms and drivers of antimicrobial resistance. The Lancet. 2016;387(10014):176-87.

2. Ventola CL. The antibiotic resistance crisis: part 1: causes and threats. Pharmacy and Therapeutics. 2015;40(4):277.

3. Wright GD. Q\&A: Antibiotic resistance: where does it come from and what can we do about it? BMC Biol. 2010;8(1):123.

4. O'Neill J. Tacking drug-resistant infections globally: final report and recommendations amr-review.org. 2016 [Available from: https:// amr-review.org/sites/default/files/160525_Final\%20paper_with\% 20cover.pdf.

5. Cotter PD, Ross RP, Hill C. Bacteriocins - a viable alternative to antibiotics? Nat Rev Microbiol. 2013;11(2):95.

6. Khadka P, Ro J, Kim H, Kim I, Kim JT, Kim H, et al. Pharmaceutical particle technologies: an approach to improve drug solubility, dissolution and bioavailability. Asian J Pharm Sci. 2014;9(6):304-16.

7. Yu LX, Amidon GL, Polli JE, Zhao H, Mehta MU, Conner DP, et al. Biopharmaceutics classification system: the scientific basis for biowaiver extensions. Pharm Res. 2002;19(7):921-5.

8. Bak A, Leung D, Barrett SE, Forster S, Minnihan EC, Leithead AW, et al. Physicochemical and formulation developability assessment for therapeutic peptide delivery-a primer. AAPS J. 2015;17(1):144-55.

9. Ryan MP, Rea MC, Hill C, Ross RP. An application in cheddar cheese manufacture for a strain of Lactococcus lactis producing a novel broad-spectrum bacteriocin, lacticin 3147. Appl Environ Microbiol. 1996;62(2):612-9.

10. Wiedemann I, Böttiger T, Bonelli RR, Wiese A, Hagge SO, Gutsmann T, et al. The mode of action of the lantibiotic lacticin 3147-a complex mechanism involving specific interaction of two peptides and the cell wall precursor lipid II. Mol Microbiol. 2006;61(2):285-96.

11. Morgan SM, O'Connor PM, Cotter PD, Ross RP, Hill C. Sequential actions of the two component peptides of the lantibiotic lacticin 3147 explain its antimicrobial activity at nanomolar concentrations. Antimicrob Agents Chemother. 2005;49(7):2606-11.

12. Bakhtiary A, Cochrane SA, Mercier P, McKay RT, Miskolzie M, Sit CS, et al. Insights into the mechanism of action of the two-peptide lantibiotic lacticin 3147. J Am Chem Soc. 2017;139(49):17803-10.

13. Ryan MP, McAuliffe O, Ross RP, Hill C. Heterologous expression of lacticin 3147 in Enterococcus faecalis: comparison of biological activity with cytolysin. Lett Appl Microbiol. 2001;32(2):71-7.
14. Rea MC, Clayton E, O'Connor PM, Shanahan F, Kiely B, Ross $\mathrm{RP}$, et al. Antimicrobial activity of lacticin 3147 against clinical Clostridium difficile strains. J Med Microbiol. 2007;56(7):940-6.

15. Piper C, Draper LA, Cotter PD, Ross RP, Hill C. A comparison of the activities of lacticin 3147 and nisin against drug-resistant Staphylococcus aureus and Enterococcus species. J Antimicrob Chemother. 2009;64(3):546-51.

16. Dobson A, Crispie F, Rea MC, O'Sullivan O, Casey PG, Lawlor PG, et al. Fate and efficacy of lacticin 3147-producing Lactococcus lactis in the mammalian gastrointestinal tract. FEMS Microbiol Ecol. 2011;76(3):602-14.

17. CDC. Antibiotic Resistance Threats in the United States, 2019.: Atlanta, GA: U.S. Department of Health and Human Services. 2019 [Available from: https://www.cdc.gov/drugresistance/pdf/ threats-report/2019-ar-threats-report-508.pdf.

18. Aslam S, Hamill RJ, Musher DM. Treatment of Clostridium difficile-associated disease: old therapies and new strategies. Lancet Infect Dis. 2005;5(9):549-57.

19. Kuijper EJ, Barbut F, Brazier JS, Kleinkauf N, Eckmanns T, Lambert ML, et al. Update of Clostridium difficile infection due to PCR ribotype 027 in Europe, 2008. Eurosurveillance. 2008;13(31):18942.

20. Radoshevich L, Cossart P. Listeria monocytogenes: towards a complete picture of its physiology and pathogenesis. Nat Rev Microbiol. 2018;16(1):32-46.

21. Gardiner GE, Rea MC, O'Riordan B, O'Connor P, Morgan SM, Lawlor PG, et al. Fate of the two-component lantibiotic lacticin 3147 in the gastrointestinal tract. Appl Environ Microbiol. 2007;73(21):7103-9.

22. Rollema HS, Kuipers OP, Both P, De Vos WM, Siezen RJ. Improvement of solubility and stability of the antimicrobial peptide nisin by protein engineering. Appl Environ Microbiol. 1995;61(8):2873-8

23. Naruse N, Tenmyo O, Tomita K, Konishi M, Miyaki T, Kawaguchi H, et al. Lanthiopeptin, a new peptide antibiotic. Production, isolation and properties of lanthiopeptin. J Antibiot (Tokyo). 1989;42(6):837-45.

24. Salomon RA, Farías RN. Microcin 25, a novel antimicrobial peptide produced by Escherichia coli. J Bacteriol. 1992; 174(22):7428-35.

25. Irvine DJ, Su X, Kwong B. Routes of delivery for biological drug products. Pharmaceutical Sciences Encyclopedia: Drug Discovery, Development, and Manufacturing. 2010:1-48.

26. Prombutara P, Kulwatthanasal Y, Supaka N, Sramala I, Chareonpornwattana S. Production of nisin-loaded solid lipid nanoparticles for sustained antimicrobial activity. Food Control. 2012;24(1-2):184-90.

27. de Mello MB, da Silva Malheiros P, Brandelli A, da Silveira NP, Jantzen MM, da Motta AdS. Characterization and antilisterial effect of phosphatidylcholine nanovesicles containing the antimicrobial peptide pediocin. Probiotics and antimicrobial proteins. 2013;5(1):43-50.

28. Martin NI, Sprules T, Carpenter MR, Cotter PD, Hill C, Ross RP, et al. Structural characterization of lacticin 3147, a two-peptide lantibiotic with synergistic activity. Biochemistry. 2004;43(11):3049-56.

29. Vertzoni M, Dressman J, Butler J, Hempenstall J, Reppas C. Simulation of fasting gastric conditions and its importance for the in vivo dissolution of lipophilic compounds. Eur J Pharm Biopharm. 2005;60(3):413-7.

30. Bannigan P, Durack E, Madden C, Lusi M, Hudson SP. Role of biorelevant dissolution media in the selection of optimal salt forms of oral drugs: maximizing the gastrointestinal solubility and in vitro activity of the antimicrobial molecule, clofazimine. ACS Omega. 2017;2(12):8969-81.

31. Patel PA, Patil SC, Kalaria DR, Kalia YN, Patravale VB. Comparative in vitro and in vivo evaluation of lipid based nanocarriers of Huperzine A. Int J Pharm. 2013;446(1-2):16-23. 
32. Shazly GA. Ciprofloxacin controlled-solid lipid nanoparticles: characterization, in vitro release, and antibacterial activity assessment. BioMed Res Int 2017.

33. Carroll J, Draper LA, O'Connor PM, Coffey A, Hill C, Ross RP, et al. Comparison of the activities of the lantibiotics nisin and lacticin 3147 against clinically significant mycobacteria. Int J Antimicrob Agents. 2010;36(2):132-6.

34. McAuliffe O, Ryan MP, Ross RP, Hill C, Breeuwer P, Abee T. Lacticin 3147, a broad-spectrum bacteriocin which selectively dissipates the membrane potential. Appl Environ Microbiol. 1998;64(2):439-45.

35. Suda S, Westerbeek A, O'Connor PM, Ross RP, Hill C, Cotter PD. Effect of bioengineering lacticin 3147 lanthionine bridges on specific activity and resistance to heat and proteases. Chem Biol. 2010;17(10):1151-60.

36. ExPASy. ExPASy: get pI/Mw. 2019 Available from: https://web. expasy.org/compute_pi/.

37. Naylor LJ. Comparison of the Mechanism of Dissolution of Hydrocortisone in Simple and Mixed Micelle Systems I SpringerLink. Pharm Res. 1993;10(6):865-70.

38. Duan Y, Dhar A, Patel C, Khimani M, Neogi S, Sharma P, et al. A brief review on solid lipid nanoparticles: part and parcel of contemporary drug delivery systems. RSC Adv. 2020;10(45):26777-91.

39. Chaudhari MB, Desai PP, Patel PA, Patravale VB. Solid lipid nanoparticles of amphotericin B (AmbiOnp): in vitro and in vivo assessment towards safe and effective oral treatment module. Drug Deliv Transl Res. 2016;6(4):354-64.

40. Mishra DK, Dhote V, Bhatnagar P, Mishra PK. Engineering solid lipid nanoparticles for improved drug delivery: promises and challenges of translational research. Drug Deliv Transl Res. 2012;2(4):238-53.

41. Rawal SU, Patel MM. Lipid nanoparticulate systems: Modern versatile drug carriers. Lipid Nanocarriers for Drug Targeting: Elsevier; 2018. p. 49-138.

42. Sadiq S, Imran M, Habib H, Shabbir S, Ihsan A, Zafar Y, et al. Potential of monolaurin based food-grade nano-micelles loaded with nisin $\mathrm{Z}$ for synergistic antimicrobial action against Staphylococcus aureus. LWT-Food Sci Technol. 2016;71:227-33.

43. Lamprecht A, Schäfer U, Lehr C-M. Size-dependent bioadhesion of micro-and nanoparticulate carriers to the inflamed colonic mucosa. Pharm Res. 2001;18(6):788-93.

44. Dianzani C, Foglietta F, Ferrara B, Rosa AC, Muntoni E, Gasco P, et al. Solid lipid nanoparticles delivering anti-inflammatory drugs to treat inflammatory bowel disease: Effects in an in vivo model. World J Gastroenterol. 2017;23(23):4200.

Publisher's Note Springer Nature remains neutral with regard to jurisdictional claims in published maps and institutional affiliations. 